\title{
Evaluatie vervangingsvraagprognoses naar opleiding en beroep
}

Citation for published version (APA):

Montizaan, R. M. (2009). Evaluatie vervangingsvraagprognoses naar opleiding en beroep. ROA. ROA Technical Reports No. 1 https://doi.org/10.26481/umarot.2009001

Document status and date:

Published: 01/01/2009

DOI:

10.26481/umarot.2009001

Document Version:

Publisher's PDF, also known as Version of record

\section{Please check the document version of this publication:}

- A submitted manuscript is the version of the article upon submission and before peer-review. There can be important differences between the submitted version and the official published version of record.

People interested in the research are advised to contact the author for the final version of the publication, or visit the DOI to the publisher's website.

- The final author version and the galley proof are versions of the publication after peer review.

- The final published version features the final layout of the paper including the volume, issue and page numbers.

Link to publication

\footnotetext{
General rights rights.

- You may freely distribute the URL identifying the publication in the public portal. please follow below link for the End User Agreement:

www.umlib.nl/taverne-license

Take down policy

If you believe that this document breaches copyright please contact us at:

repository@maastrichtuniversity.nl

providing details and we will investigate your claim.
}

Copyright and moral rights for the publications made accessible in the public portal are retained by the authors and/or other copyright owners and it is a condition of accessing publications that users recognise and abide by the legal requirements associated with these

- Users may download and print one copy of any publication from the public portal for the purpose of private study or research.

- You may not further distribute the material or use it for any profit-making activity or commercial gain

If the publication is distributed under the terms of Article $25 \mathrm{fa}$ of the Dutch Copyright Act, indicated by the "Taverne" license above, 


\section{Evaluatie vervangingsvraagprognoses naar opleiding en beroep}

Raymond Montizaan

ROA-TR-2009/1

Maart 2009

Researchcentrum voor

Onderwijs en Arbeidsmarkt

Postbus 616

6200 MD Maastricht

E-mail: $\quad$ secretary@roa.unimaas.nl

Internet: $\quad$ www.roa.unimaas.nl

Universiteit Maastricht

Faculteit der Economische Wetenschappen en Bedrijfskunde 
ISBN-978-90-5321-473-2

Sec09.018.doc 


\section{Inhoud}

Bladzijde

Voorwoord

1 Inleiding 1

1.1 Uitgangspunten 1

1.2 Doel en opzet prognoses 3

1.3 Opzet van het rapport 5

2 Een methode voor de empirische evaluatie 6

2.1 Inleiding 6

2.2 Het evaluatiecriterium 7

$\begin{array}{ll}2.3 \text { De oorzaak van voorspelfouten } & 10\end{array}$

2.4 De evaluatie van kwalitatieve typeringen 16

3 De vervangingsvraag tot $2006 \quad 17$

3.1 Inleiding 17

3.2 Prognosemethodiek 18

3.3 Empirische analyse van de vervangingsvraagprognoses naar beroep $\quad 21$

3.4 Empirische evaluatie van de vervangingsvraagprognoses naar opleiding 34

4 Vergelijking realisatie cohort-componenten- methode en paneldata 45

$\begin{array}{llr}5 & \text { Conclusies } & 47\end{array}$

$\begin{array}{ll}\text { Literatuur } & 50\end{array}$ 



\section{Voorwoord}

Deze evaluatiestudie heeft plaatsgevonden in het kader van het Project OnderwijsArbeidsmarkt (POA). Dit project wordt gefinancierd door het Ministerie van Onderwijs, Cultuur en Wetenschap (OCW), het Uitvoeringsinstituut Werknemersverzekeringen (UWV), het UWV Werkbedrijf, het Ministerie van Landbouw, Natuur en Voedselkwaliteit (LNV), de samenwerkende kenniscentra voor beroepsonderwijs en bedrijfsleven COLO, Randstad Nederland en de Raad voor Werk en Inkomen (RWI). De auteur bedankt de leden van de begeleidingscommissie van het Project Onderwijs-Arbeidsmarkt voor het commentaar op een eerdere versie. 



\section{$1 \quad$ Inleiding}

\subsection{Uitgangspunten}

Het Researchcentrum voor Onderwijs en Arbeidsmarkt (ROA) maakt in het kader van het Arbeidsmarktinformatiesysteem (AIS) iedere twee jaar middellangetermijnprognoses voor de arbeidsmarktperspectieven van opleidingen en beroepen. De laatste prognoses zijn terug te vinden in De arbeidsmarkt naar opleiding en beroep tot 2012 (ROA, 2007) en het bijbehorende Arbeidsmarktinformatiesysteem (AIS). De prognoses uit het verleden worden regelmatig geëvalueerd. In dit evaluatierapport zal een specifiek element van het prognosemodel worden geëvalueerd dat in 2001 is gebruikt voor het opstellen van de vervangingsvraag voor de periode 2001-2006 (ROA, 2001). De methodiek van de vervangingsvraag is beschreven in Methodiek arbeidsmarktprognoses en -indicatoren 2001-2006 (ROA, 2002). Bij de evaluatie in dit rapport wordt specifiek ingegaan op welke factoren de afwijkingen tussen de voorspelde en de gerealiseerde vervangingsvraag kunnen verklaren. Tevens zal de kwaliteit van de prognoses van de vervangingsvraag voor de periode 2001-2006 zoveel mogelijk worden vergeleken met de kwaliteit van de eerdere prognoses voor de vervangingsvraag, welke terug te vinden zijn in Dupuy (2005).

Het evalueren van prognoses is met name van belang met het oog op toekomstige prognoseactiviteiten. Dat geldt niet alleen voor de opstellers van de prognoses maar ook voor de gebruikers. Voor de gebruikers van de prognoses over de toekomstige arbeidsmarktontwikkelingen is het nuttig informatie te hebben over de mate van betrouwbaarheid van de prognoses. In Borghans (1993) wordt getoond dat publieke voorspellingen een positieve invloed op de studiekeuze van leerlingen en daarmee op de werking van de arbeidsmarkt hebben, mits leerlingen een redelijk beeld hebben van de bruikbaarheid van deze prognoses. Voor het inzicht in de bruikbaarheid van de prognoses zijn twee zaken van belang. Ten eerste dient het voor gebruikers duidelijk te zijn op grond van welke argumenten een prognose tot 
stand is gekomen. Het totaalbeeld dat een prognose schetst dient verbijzonderd te worden naar de componenten waaruit zij is opgebouwd, zodat duidelijk wordt op grond waarvan bepaalde ontwikkelingen verwacht worden. Dit maakt het mogelijk de prognoses te vergelijken met de eigen verwachtingen over de toekomstige arbeidsmarktontwikkelingen en/of diverse andere informatiebronnen. Ten tweede is het van belang dat gebruikers een beeld hebben van de gemiddelde trefzekerheid van de voorspellingen, omdat dit mede bepaalt in welke mate zij rekening zouden moeten houden met de prognoses van het informatiesysteem. Om aan deze eis te voldoen is het derhalve belangrijk na te gaan op welke punten de prognoses redelijk trefzeker zijn, en op welke punten de onzekerheden liggen. Ook moet bekeken worden op welke manier de mate van onzekerheid tot uitdrukking komt in de wijze waarop de prognoses worden gepubliceerd.

De evaluatie van de prognoses geeft informatie die benut kan worden voor een verdere verbetering van het de prognosemodellen. Om deze reden is een goede evaluatie van de prognoses ook voor de opstellers van de prognoses van groot belang. Bij het opstellen van prognoses wordt op basis van inzichten in het functioneren van de arbeidsmarkt een keuze gemaakt tussen de vele mogelijke manieren om de arbeidsmarkt te modelleren. Indien alleen de kwaliteit van de data de kwaliteit van de prognoses zou bepalen, zou de enige les die uit de evaluatie getrokken kan worden, een roep om meer of betere data zijn. Een evaluatie van de prognoses kan echter ook nieuwe inzichten geven over de bruikbaarheid van de gehanteerde methode. Bovendien kan worden nagegaan of de aanpassingen in de methodiek die op basis van eerdere evaluatiestudies hebben plaatsgevonden ook in de verwachte verbeteringen hebben geresulteerd.

Naast de opstellers en de gebruikers hebben vanzelfsprekend ook financiers belang bij een evaluatie van de voorspellingen. Aan de ene kant kan deze evaluatie informatie geven omtrent de prioriteiten die gelegd moeten worden bij de verdere ontwikkeling van het informatiesysteem. Aan de andere kant is het voor de 2 
opdrachtgevers belangrijk te weten in hoeverre de prognoses bruikbaar zijn voor de door hen beoogde gebruiksdoelen.

\subsection{Doel en opzet prognoses}

De vervangingsvraag is de vraag die ontstaat vanwege (vervroegde) pensionering, arbeidsongeschiktheid, tijdelijke terugtrekking van de arbeidsmarkt en baan-baan mobiliteit voor zover deze plaatsvindt tussen verschillende beroepsgroepen. De uitbreidingsvraag en de vervangingsvraag leveren samen het verwachte aantal baanopeningen per beroepsgroep op. Verondersteld is dat deze baanopeningen de voor studie- en beroepskeuzedoeleinden relevante grootheid is. De vervangingsvraag naar opleiding is apart berekend, omdat deze niet uit de vervangingsvraag naar beroep kan worden afgeleid. De vervangingsvraag naar beroep wijkt af van de vervangingsvraag naar opleiding omdat baan-baan mobiliteit tussen beroepsgroepen op zichzelf niet leidt tot vervangingsvraag naar opleiding. Daarentegen leidt het behalen van een diploma van werkenden in een andere opleidingsrichting of op een hogere opleidingsniveau wel tot vervangingsvraag naar opleiding maar niet per se tot vervangingsvraag naar beroep. Tezamen vormen de vervangingsvraag en de uitbreidingsvraag de totale vraag naar nieuwkomers met de desbetreffende beroepsuitoefening of opleidingsachtergrond. Deze totale vraag geeft het antal baanopeningen weer dat beschikbaar komt voor schoolverlaters. Door de baanopeningen te confronteren met de instroom van schoolverlaters op de arbeidsmarkt, wordt een indicatie verkregen van de te verwachten discrepanties op de arbeidsmarkt, gedifferentieerd naar opleiding en beroep.

De prognosegegevens en de overige arbeidsmarktgegevens die in het Arbeidsmarktinformatiesysteem (AIS) worden opgenomen zijn bedoeld voor zowel studiekiezers als voor andere actoren op de arbeidsmarkt zoals beleidsmakers (de overheid, de arbeidsvoorzieningsorganisatie, de sociale partners en het onderwijsveld) en het bedrijfsleven. De vervangingsvraagprognoses vormen dus een deel van alle informatie die beschikbaar is voor deze actoren. De doelstelling om 
informatie te genereren die bruikbaar is voor de studie- en beroepskeuzevoorlichting betekent dat de (vervangingsvraags)prognoses betrekking moeten hebben op aspecten die van belang kunnen zijn voor de studie- of beroepskeuzebeslissingen. Dat wil zeggen dat de prognoses inzicht moeten geven in de situatie op de arbeidsmarkt die een leerling aan zal treffen vanaf het moment dat deze, na zijn studie te hebben voltooid, tot de arbeidsmarkt toetreedt. Deze voorwaarde legt dus eisen op aan de periode waarop de prognoses betrekking hebben en aan de groep op de arbeidsmarkt waarvoor ze relevant zijn. De einddatum van de prognoseperiode dient dus te vallen in de tijd dat de schoolverlaters de arbeidsmarkt zullen betreden en de verwachte perspectieven dienen op de toekomstige arbeidsmarktsituatie van de nieuwkomers gebaseerd te zijn. Echter ook voor werkgevers en beleidsmakers is dergelijke informatie over de middellange termijn van belang bij bijvoorbeeld strategische beslissingen over het recruteringsbeleid, het HRM-beleid, en het onderwijs-, arbeidsmarkt- en technologiebeleid.

De prognoseresultaten dienen zoveel mogelijk geformuleerd te worden in algemeen gehanteerde begrippen en zo min mogelijk statistisch of economisch jargon te bevatten. Met name met betrekking tot statistische uitspraken over de betrouwbaarheid van de prognoses is een vertaling van groot belang. Bepaalde meer algemene beschrijvingen van de arbeidsmarkt kunnen voor beleidsmakers zeer relevant zijn, maar zijn voor individuen pas bruikbaar na een vertaling naar het individueel niveau. $Z_{o}$ is de totale vervangingsvraag voor een bepaalde opleidingscategorie vanuit een beleidsoogpunt interessant, maar is het voor een leerling belangrijker om te weten wat hiervan de consequentie is voor zijn of haar individuele kans op een bepaald soort werk na afloop van de studie.

Om de kwantitatieve gegevens van de vervangingsvraagprognoses (en ook de andere prognoses, actuele data en indicatoren) toegankelijker te maken voor een bredere groep van gebruikers worden deze getransformeerd naar kwalitatieve 4 
typeringen. Op basis van de waargenomen waarden van de variabelen is telkens een classificatie gemaakt op een vijf-punts-schaal met de volgende typeringen 'erg laag', 'laag', 'gemiddeld', 'hoog' of 'erg hoog'. De bedoeling van deze kwalititatieve typeringen is om de kwantitatieve gegevens beter toegankelijk te maken voor mensen die niet gewend zijn met dergelijke cijfers te werken. Ten eerste hoeft men zich nu niet te verdiepen in de meeteenheid van de variabele. Ten tweede krijgt men meteen een relatieve typering, zodat men geen inzicht hoeft te hebben in de spreiding van de variabele. Ten derde zorgt de verdeling in intervallen voor een typering die minder exact overkomt dan de cijfers zelf. Hiermee wordt de suggestie van nauwkeurigheid tot achter de komma vermeden en krijgen met name de arbeidsmarktprognoses een zekere bandbreedte.

Bij de empirische evaluatie moet rekening worden gehouden met de gezichtpunten van de gebruikers van de arbeidsmarktinformatie. Dit betekent dat het gehanteerde evaluatie-criterium, waarmee de omvang van de voorspelfouten wordt vastgesteld, vooral moet laten zien welke consequenties deze voorspelfouten hebben voor de individuele studie- en beroepskeuze of voor beslissingen van werkgevers of beleidsmakers. Bij een beoordeling van de prognoses vanuit een andere doelstelling zullen dan mogelijk ook andere eisen gesteld moeten worden aan zowel de inhoud en vorm van de informatie als aan het gehanteerde evaluatiecriterium. In hoofdstuk 2 wordt beargumenteerd dat een evaluatiecriterium vanuit de studie- en beroepskeuzeoptiek gebaseerd dient te zijn op procentuele voorspelfouten, terwijl het vanuit de beleidsoptiek wellicht meer voor de hand ligt om de absolute aantallen in de voorspelfout te gebruiken. De keuze van het evaluatiecriterium wordt verder besproken in paragraaf 2.2.

\subsection{Opzet van het rapport}

Zoals reeds eerder gezegd, wordt in dit rapport specifiek gekeken naar de vervangingsvraagprognoses. In Hoofdstuk 2 wordt de evaluatiesystematiek besproken. In Hoofdstuk 3 wordt vervolgens nader ingegaan op hoe de 
vervangingsvraag tot stand is gekomen en wordt deze empirisch geëvalueerd. De kwaliteit van de vervangingsvraag prognoses zal daarbij worden vergeleken met de kwaliteit van de eerder gemaakte prognoses. In Hoofdstuk 4 worden ten slotte de belangrijkste bevindingen kort samengevat en wordt aangegeven welke aandachtspunten er uit deze evaluatie-studie volgen voor de verdere ontwikkeling van het informatiesysteem.

\section{Een methode voor de empirische evaluatie}

\subsection{Inleiding}

De methode van evalueren komt vrijwel overeen met de methode die is gehanteerd in de vorige evaluatie-rapporten (zie bijv. Smits en Diephuis, 2001; Dupuy, 2005). Het uitgangspunt voor deze methode vormen de vragen die volgens Granger en Newbold (1986) een objectieve evaluatie van de vervangingsvraagprognoses moet beantwoorden:

(1) Zijn de voorspellingen beter dan de beschikbare alternatieven?

(2) Hoe 'goed' zijn de voorspellingen?

(3) Kan de methode waarmee de voorspellingen zijn opgesteld zodanig aangepast worden dat een verbeterde voorspelkwaliteit verwacht mag worden?

In dit hoofdstuk komen alle onderdelen van de evaluatie kort aan de orde. Allereerst wordt in paragraaf 2.2 het gehanteerde evaluatiecriterium besproken. Dit criterium geeft met name een waardering van het 'verlies' dat ontstaat door de voorspelfouten. Om meer zicht te krijgen op de oorzaken van de voorspelfouten worden vervolgens in paragraaf 2.3 enkele toetsen besproken. Er wordt achtereenvolgens ingegaan op de concentratie van voorspelfouten, mogelijke verklaringen voor de voorspelfouten en de over- en onderschatting van 
veranderingen. In paragraaf 2.4 wordt ingegaan op de evaluatie van kwalitatieve typeringen.

\subsection{Het evaluatiecriterium}

Uitgangspunt bij de beoordeling van de vervangingsvraagprognoses van het Arbeidsmarktinformatiesysteem is, zoals gezegd, de doelstelling dat de prognoses geschikt moeten zijn voor de studie- en beroepskeuze. De voorspellingen van de ontwikkelingen van de vervangingsvraag zijn geformuleerd in aantallen personen. Voor een individuele leerling is echter niet de totale vervangingsvraag, het totale aantal werkzame personen in een beroep of een opleiding, of de absolute voorspelfout interessant, maar gaat het vooral om de relatieve voorspelfout: $\left(x_{i}-\hat{x}_{i}\right) / y_{i}$, waarin $x_{i}$ staat voor de realisatie van een voorspelde grootheid voor beroep of opleiding $i$, en $\hat{x}_{i}$ de prognose voor dezelfde grootheid aanduidt. $y_{i}$ geeft het aantal werkzame personen in de voorspelde categorie aan.

Onder de veronderstelling dat deze relatieve maatstaf normaal verdeeld is, is het zinvol om het kwadraat hiervan als verlies van de afzonderlijke prognose te beschouwen (Granger en Newbold, 1986).

$V_{i}\left(\hat{x}_{i}\right)=\left(\frac{x_{i}-\hat{x}_{i}}{y_{i}}\right)^{2}$

Het individuele verliescriterium $\mathrm{V}_{\mathrm{i}}$ geeft dus bij benadering het verlies dat relevant is voor de keuze van een individuele leerling, die eventueel het desbetreffende beroep of de desbetreffende opleiding zal kiezen. In dit rapport zal voor de vervangingsvraagprognose een tabel gepresenteerd worden, waarin prognoses, realisatie, voorspelfout en het verlies per beroepsklasse of opleidingstype wordt weergegeven. Hoewel een dergelijk overzicht een eerste indruk van de kwaliteit van de voorspellingen geeft en daardoor mogelijke problemen bij de prognoses aan het licht kan brengen, moet bij de interpretatie van dit overzicht gewaakt worden voor ad hoc redeneringen. 
Om een beeld te kunnen krijgen van de totale kwaliteit van de vervangingsvraag prognoses, is het niet zo zinvol de prognoses voor iedere beroepsklasse of opleidingstype afzonderlijk in beschouwing te nemen, omdat veel voorspelfouten op zich een incidenteel karakter hebben. Het is moeilijk hieruit lessen te trekken. Doordat in het Arbeidsmarktinformatiesysteem prognoses zijn gemaakt voor 127 beroepsklassen en 104 opleidingstypen, is het gezien de hoeveelheid informatie dan ook wenselijk het verlies over alle beroepsklassen of opleidingstypen te aggregeren. Op deze wijze kan beter gekeken worden naar de systematiek in de prognosefouten. Deze aggregatie maakt het mogelijk uitspraken te doen over de kansverdeling van het verlies over alle beroepsklassen of opleidingstypen in plaats van een afzonderlijke beschouwing van iedere voorspelling te maken. De afzonderlijke verliezen per beroepsklassen of opleidingstypen kunnen worden geaggregeerd door op basis van het individuele verlies, $V_{i}$, het gemiddelde verlies te berekenen.

Bij het aggregeren van dit criterium moet er rekening mee worden gehouden dat er veel meer nieuwkomers op de arbeidsmarkt in een groot beroep of een grote opleidingscategorie terecht komen dan in een kleine. Door te wegen naar de omvang van het beroep of de opleidingscategorie wordt het gemiddeld verlies bepaald. Dit is het evaluatiecriterium op geaggregeerd niveau:

$\mathrm{GV}(\hat{\mathrm{x}})=\sum_{\mathrm{i}} \frac{\mathrm{y}_{\mathrm{i}}}{\mathrm{y}^{\text {tot }}} \mathrm{V}_{\mathrm{i}}\left(\hat{\mathrm{x}}_{\mathrm{i}}\right)=\sum_{\mathrm{i}} \frac{\mathrm{y}_{\mathrm{i}}}{\mathrm{y}^{\text {tot }}}\left(\frac{\mathrm{x}_{\mathrm{i}}-\hat{\mathrm{x}}_{\mathrm{i}}}{\mathrm{y}_{\mathrm{i}}}\right)^{2}=\sum_{\mathrm{i}} \frac{1}{\mathrm{y}^{\text {tot }}} \frac{\left(\mathrm{x}_{\mathrm{i}}-\hat{\mathrm{x}}_{\mathrm{i}}\right)^{2}}{\mathrm{y}_{\mathrm{i}}}$

Hierin is $y^{\text {tot }}=\sum_{\mathrm{i}} \mathrm{y}_{\mathrm{i}}$ de totale gerealiseerde omvang van de werkzame personen, terwijl het gemiddeld verlies (GV) het verlies van een gemiddelde leerling aangeeft.

De verliesfunctie geeft een schatting van de spreiding van de voorspellingen rond de realisatie en daarmee een antwoord op de tweede eis die Granger en Newbold (1986) stellen aan een objectieve evaluatie. Op grond van dit cijfer is het echter niet mogelijk een duidelijke uitspraak te doen over de kwaliteit van de prognoses. 8 
Er is immers geen informatie beschikbaar over wat een redelijke waarde voor het gemiddeld verlies zou zijn. Om te voorzien in een dergelijke beoordelingsmaatstaf kan de destijds gehanteerde prognose vergeleken worden met de voorspelkwaliteit van andere beschikbare prognoses, conform de eerste eis uit de lijst van Granger en Newbold. Door de verhouding te nemen tussen de voorspelkwaliteit van de prognose en de voorspelkwaliteit van een referentievoorspelling, ontstaat een score die kleiner is dan 1 als de prognose beter is dan de referentieprognose en groter dan 1 als de prognose slechter is:

$$
\mathrm{S}\left(\hat{\mathrm{x}}, \mathrm{x}^{\text {ref }}\right)=\frac{\mathrm{GV}(\hat{\mathrm{x}})}{\mathrm{GV}\left(\mathrm{x}^{\text {ref }}\right)}
$$

Om invulling te kunnen geven aan de score-definitie, moet een bepaalde prognose als referentieprognose worden bestempeld. Evenals bij de vorige evaluaties van de ROA-prognoses (bijv. Smits en Diephuis, 2001; Dupuy, 2005) worden de vervangingsvraagprognoses vergeleken met de beschikbare arbeidsmarktinformatie in de situatie waarin gebruikers (onder wie leerlingen) die voor een bepaalde (studiekeuze)beslissing staan zouden verkeren indien ze geen prognoses uit het informatiesysteem tot hun beschikking zouden hebben (in het basisjaar van de prognoses). Voor de vervangingsvraag geldt echter dat het niet aannemelijk is dat gebruikers (c.q. leerlingen) op de hoogte zijn van de omvang van de vervangingsvraag op dat moment. Derhalve wordt de gemiddelde voorspelde vervangingsvraag als percentage van het antal werkzame personen gebruikt als een referentieprognose voor de vervangingsvraag per beroep of opleiding. Hiermee wijkt de referentieprognose voor de vervangingsvraag dus af van die voor de andere elementen van het prognosemodel. ${ }^{1}$

1. Voor de andere elementen van het prognosemodel (uitbreidingsvraag, instroom van schoolverlaters, etc.) wordt verondersteld dat leerlingen bij gebrek an informatie over de toekomst (i.e. prognoses) hun keuze baseren op de huidige arbeidsmarktsituatie. Daarom wordt voor deze elementen de situatie in het basisjaar als referentieprognose gehanteerd. Deze prognoses worden ook wel Same As Before prognose (SAB) genoemd. 
Een laatste punt van afweging is de schaal waarop de prognoses geëvalueerd worden. Veel beleidsmakers lijken met name te hechten aan de evaluatie van de absolute prognoseaantallen. In het kader van de studie- en beroepskeuzevoorlichting gaat het er echter niet alleen om een goede inschatting te maken van de absolute positie van een beroep of opleiding, maar vooral ook om het in beeld brengen van de relatieve positie. Daarom wordt de evaluatie in dit rapport doorgaans naast de absolute prognoses ook uitgevoerd op een prognose die gecorrigeerd is voor het totale volume-effect. Dat wil zeggen, de prognoses zijn vermenigvuldigd met een factor zodanig dat over alle categorieën geaggregeerd de prognoses gelijk zijn aan de realisatie. Deze prognoses worden aangeduid als de relatieve prognoses.

\subsection{De oorzaak van voorspelfouten}

Het gemiddeld verlies en de score die in de vorige paragraaf zijn besproken, geven informatie over de kwaliteit van de gemaakte voorspellingen. Op zich geven zij echter niet aan waardoor een prognose goed of slecht is uitgevallen. Op deze wijze wordt derhalve niet duidelijk hoe de prognosemethodiek op grond van de evaluatie-resultaten kan worden aangepast. Dit laatste is volgens Granger en Newbold (1986) het derde belangrijke punt bij het uitvoeren van een objectieve evaluatie. Om op basis van deze evaluatie conclusies te kunnen trekken die inzicht geven in de aard van de problemen die bij de prognoses verwacht kunnen worden en om consequenties met betrekking tot de gehanteerde methodiek te kunnen trekken, worden in aanvulling op de in de vorige paragraaf beschreven evaluatiemaatstaf, enkele analyses uitgevoerd die inzicht verschaffen in de oorzaken van de gemaakte voorspelfouten. 


\section{Verklaring van voorspelfouten}

Een overzicht van separate voorspelfouten kan bruikbaar zijn voor een subjectieve evaluatie. Derhalve worden in dit rapport tabellen met voorspelfouten voor elke beroepsgroep of opleidingstype getoond. Een nadeel van het analyseren van de voorspelkwaliteit van de afzonderlijke opleidingstypen of beroepsgroepen is dat het systematische karakter van voorspelfouten niet aan het licht kunnen komen. Iedere voorspelfout wordt in dat geval als een incident op zich beschouwd waardoor de structuur achter deze voorspelfouten verloren gaat.

Het verschil tussen de voorspelling en werkelijke uitkomst kan het best worden gezien als de uitkomst van een stochastische variabele. Op het moment dat de voorspeller de prognose opstelt, is het niet mogelijk om te voorspellen hoe groot de voorspelfouten zullen zijn. Voor de evaluatie is het echter interessant om een idee te krijgen van de distributie van deze 'random' variabele. In de empirische evaluatie wordt derhalve een schatting gemaakt van de standaardafwijking van de relatieve voorspelfouten, onder de veronderstelling dat de voorspelfouten normaal verdeeld zijn:

$\varepsilon_{\mathrm{i}}=\mathrm{x}_{\mathrm{i}}-\hat{\mathrm{X}}_{\mathrm{i}} \sim \mathrm{N}\left(\mu_{\mathrm{i}}, \sigma_{\mathrm{i}}^{2}\right)$

met:

$\sigma_{\mathrm{i}}=\left(\mathrm{y}_{\mathrm{i}}\right)^{\alpha} \mathrm{e}^{\mathrm{z}_{\mathrm{i}} \beta}$

$\mu_{\mathrm{i}}=\theta\left(\hat{\mathrm{x}}_{\mathrm{i}}-\mathrm{x}_{\mathrm{i}}^{\mathrm{ref}}\right)$

Hierin is $\mathrm{x}_{\mathrm{i}}$ wederom de te voorspellen grootheid (vervangingsvraag per beroepsgroep of opleidingstype) in het prognosejaar, $\hat{x}_{i}$ de prognose van deze grootheid, $x_{i}^{\text {ref }}$ de referentieprognose (i.e. de 'naïeve' prognose) en $Z_{i}$ zijn de andere 
verklarende variabelen voor de standaardafwijking van de prognoses. De variabele $y_{i}$ duidt op de omvang van de werkgelegenheid voor het opleidingstype of de beroepsgroep. Bij prognoses van de werkgelegenheid geldt dus dat $y_{i}=x_{i}$. Voor grotere beroepsgroepen of opleidingstypen kan verwacht worden dat de voorspelfout eveneens groter is. $\sigma_{i}$ is een parameter voor de standaardafwijking van de voorspelfout. Vergelijking (2.5) is zo gespecificeerd dat deze standaardafwijking altijd positief is. In vergelijking (2.6) is $\mu_{\mathrm{i}}$ de verwachte waarde van de te voorspellen grootheid als er wordt gecorrigeerd voor een systematische over- of onderschatting van veranderingen. Op beide aspecten wordt hierna verder ingegaan.

\section{Verklaring van de standaardafwijking}

Als eerste wordt met vergelijking (2.4) - (2.6) onderzocht of er verklarende variabelen zijn voor de standaardafwijking van de voorspelfout. De eerste factor in vergelijking (2.5), de grootte van de beroepsgroep of opleidingstype $\mathrm{y}_{\mathrm{i}}$, is opgenomen om het schaaleffect te kunnen vaststellen. Er kan verwacht worden dat grotere beroepsgroepen of opleidingstypen ook te maken hebben met grotere voorspelfouten, maar waarschijnlijk zal deze voorspelfout niet volledig proportioneel toenemen. $\alpha$ zal dus waarschijnlijk kleiner zijn dan 1 en groter dan 0 . De keuze van de overige verklarende variabelen voor de omvang van de standaarddeviatie van de voorspelfouten $\left(Z_{i}\right)$ hangt af van de grootheid die in beschouwing wordt genomen. Vergelijkbaar met de in de vorige paragraaf gemaakte indeling kan hierbij zowel gedacht worden aan inhoudelijke variabelen als aan variabelen die te maken hebben met de gehanteerde methodiek.

Het Arbeidsmarktinformatiesysteem bevat ook zogenaamde risico-indicatoren, namelijk de uitwijkmogelijkheden naar andere bedrijfsklassen (voor beroepsgroepen), de uitwijkmogelijkheden naar bedrijfsklassen en beroepsgroepen (voor de opleidingstypen), en de conjunctuurgevoeligheid van de werkgelegenheid (voor 
beroepsgroepen én opleidingstypen). De uitwijkmogelijkheden geven bijvoorbeeld aan in welke mate de werkgelegenheid in een beroepsgroep gespreid is over verschillende bedrijfssectoren. ${ }^{2}$ Als deze spreiding groot is, zal een onverwachte verandering in een bepaalde bedrijfstak relatief weinig invloed hebben op de ontwikkelingen in die beroepsgroep. Verder geeft deze spreiding ook aan dat, indien er een tegenvallende vraag in één van de bedrijfsgroepen optreedt, er waarschijnlijk wel mogelijkheden zijn om in andere bedrijfssectoren werk te vinden. De conjunctuurgevoeligheid geeft aan in welke mate de werkgelegenheid van een beroepsgroep of opleidingstype meefluctueert met de conjunctuurgolven. Een hoge conjunctuurgevoeligheid betekent een grotere kans dat in de latere loopbaan de arbeidsmarktperspectieven op een gegeven moment verslechteren. Het ligt voor de hand te veronderstellen dat deze risico-indicatoren indirect ook een indicatie vormen voor de voorspelkwaliteit van de betreffende categorie. Deze indicatoren zijn mede bedoeld om een beeld te geven van de gevoeligheid van bepaalde beroepsgroepen of opleidingstypen voor exogene invloeden. Er kan dus verwacht worden dat er een samenhang bestaat tussen deze risico-indicatoren en de omvang van de voorspelfout. De methode op basis van (2.4) en (2.5) kan daardoor ook gebruikt worden om deze risico-indicatoren indirect te evalueren.

\section{Over- of onderschatting van veranderingen}

Vergelijking (2.6) geeft een indicatie van de mate waarin er over- of onderschatting van de veranderingen heeft plaatsgevonden. Een belangrijke component in de prognoses is veelal de trend in de te voorspellen grootheid. Een cruciaal punt bij het extrapoleren van bestaande trends is de wijze waarop deze extrapolatie plaats

2. Idem voor de spreiding van opleidingstypen over bedrijfsklassen of beroepsgroepen. Net als bij beroepsgroepen geven deze spreidingsindicatoren een indruk van de gevoeligheid van de prognoses, maar ook meer in het algemeen wordt op deze wijze aangegeven in hoeverre men met het kiezen voor een bepaalde opleiding afhankelijk is van de arbeidsmarktsituatie binnen een bepaalde beroepsgroep of bedrijfssector. 
dient te vinden. Het zonder meer doortrekken van trends leidt vaak, zeker op de langere termijn, tot onwaarschijnlijke resultaten. In dat geval wordt soms de trend helemaal niet opgenomen in de prognose, of wordt er een aanpak gekozen waarbij de invloed van de trend afneemt in de loop van de tijd. Vergelijkbare problemen doen zich in principe voor bij iedere verklarende variabele. Als een schatting van een parameter toevallig hoog uitvalt, zal men, wanneer de prognose op deze hoge parameter-waarde wordt gebaseerd, de invloed van deze variabele overschatten. Derhalve wordt er vaak bij niet significante waardes van de parameterschatting gekozen voor het negeren van de parameter bij het opstellen van de prognose.

\section{Figuur 2.1}

De mogelijke waarden van de onderschattingscoëfficiënt $\theta$ bij een over- of onderschatting van veranderingen

Realisatie

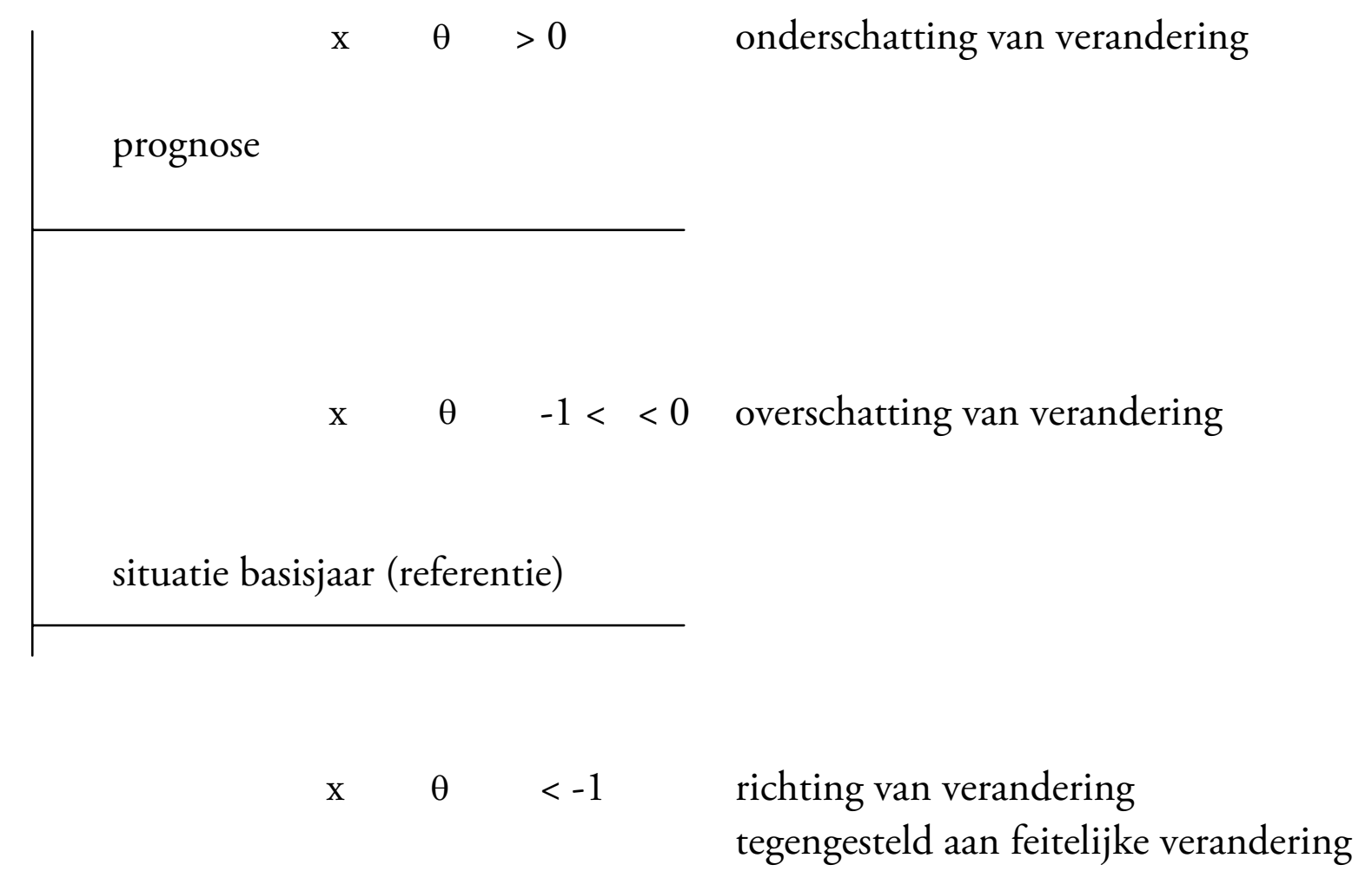


Een evaluatie is een geschikt middel om te bekijken in hoeverre de geschatte invloeden van de exogene variabelen in het verleden op een juiste manier zijn doorgetrokken naar de toekomst. Een te voorzichtige extrapolatie zal een onderschatting van verandering bewerkstelligen, terwijl een overdreven extrapolatie een overschatting van verandering is (zie Theil, 1958; en Borghans, 1993).

Op basis van deze vergelijking is het mogelijk een verwachting van het verschil tussen de realisatie en de prognose te formuleren. De rechterkant van vergelijking (2.6) bevat alleen grootheden die bekend waren op het moment dat de prognose werd opgesteld. Daardoor zou het destijds in principe mogelijk zijn geweest een betere prognose op te stellen die deze over- of onderschatting van veranderingen niet bevatte. Figuur 3.1 geeft aan wat de betekenis is van bepaalde parameterwaarden van $\theta$. In de figuur is verondersteld dat de prognose hoger uitvalt dan de waarde van de grootheid die bekend was in het basisjaar (c.q. de referentieprognose). Het omgekeerde is echter ook mogelijk. Dan ontstaat een situatie die het spiegelbeeld is van de in figuur 3.1 geschetste situatie.

In de figuur zijn drie gebieden te onderscheiden met twee grenswaarden. Als $\theta=0$ dan is gemiddeld genomen de realisatie gelijk aan de prognose. De kwaliteit van de prognose kan dan weliswaar nog slecht zijn, maar er vindt geen systematische overof onderschatting van de veranderingen plaats. Als $\theta>0$ dan ligt de realisatie van de voorspelde grootheid gemiddeld verder van de waarde in het basisjaar af dan de prognose van de waarde in het basisjaar afligt. Er is dan dus een onderschatting van veranderingen. Omgekeerd betekent $\theta<0$ dat de realisatie gemiddeld dichter bij de waarde in het basisjaar ligt dan de prognose. Er is dan dus sprake van een overschatting van veranderingen. Hierbij wordt verondersteld dat $\theta>-1$. Als $\theta=-1$ dan is de overschatting van de veranderingen totaal. Dat wil zeggen dat in dat geval iedere voorspelde verandering geen enkele informatieve waarde had en men net zo goed de referentieprognose als prognose had kunnen hanteren. Als $\theta$ kleiner is dan -1 , dan is er zelfs sprake van een omkeringseffect. Dit betekent dat 
daar waar dalingen werden voorspeld er gemiddeld sprake was van een stijging, terwijl er bij voorspellingen van stijgingen gemiddeld een daling is opgetreden.

Een over- of onderschatting van veranderingen kan veroorzaakt worden een te hoge of te lage gemiddelde prognose. Als relatieve prognoses worden geanalyseerd speelt dit echter geen rol meer. In dat geval betekent een overschatting van veranderingen dat de voorspelde groei gemiddeld lager uitviel dat verwacht, terwijl tegelijkertijd ook de voorspelde krimp minder negatief uitviel dan voorzien.

Een overschatting van veranderingen hoeft niet alleen veroorzaakt te zijn door het te ver doortrekken van trends, maar is vaak het gevolg van een grote storingscomponent in de prognoses. Als prognoses naast een informatief gedeelte ook ruis bevatten kan het zinvol zijn de voorspelde veranderingen gedeeltelijk te negeren. Dergelijke ruis wordt doorgaans veroorzaakt door meetfouten in de gebruikte data, bijvoorbeeld vanwege de steekproeffout. Des te groter deze storingscomponent des te voorzichtiger men zou moeten zijn met het hanteren van de prognoses. In vergelijking (2.6) wordt dit aangegeven door een waarde van $\theta$ die dicht bij -1 ligt.

De vergelijkingen (2.4) - (2.6) worden uiteindelijk door middel van een OLSregressie geschat met daarin de logaritme van de relatieve voorspelfouten (voorspelfouten zijn zo gespecificeerd dat ze altijd positief zijn) als afhankelijke variabele en een indicator voor overschatting- of onderschatting, de risicoindicatoren (i.e. spreiding over beroepen of sectoren, conjunctuurgevoeligheid van de werkgelegenheid), de logaritme van het aantal werkenden in een beroepsgroep en eventuele overige controlevariabelen als regressors.

\subsection{De evaluatie van kwalitatieve typeringen}

De geschetste evaluatiemethode had tot nog toe betrekking op de puntvoorspellingen die voortkomen uit de prognosemodellen van het informatiesysteem. De uiteindelijke presentatie van de prognoses van de vervangingsvraag heeft echter 16 
plaatsgevonden door middel van een kwalitatieve typering van de prognoseresultaten. In deze evaluatiestudie worden ook deze kwalitatieve typeringen geëvalueerd. Hiertoe worden ontwikkelingen die feitelijk hebben plaatsgevonden volgens hetzelfde indelingsschema voorzien van een kwalitatieve typering, waarna kan worden nagegaan in hoeveel gevallen de oorspronkelijke typering overeenkomt met deze realisatie van de netto vervangingsvraag (zie ook De Grip, Heijke en Berendsen, 1991). Een dergelijke evaluatie wordt gemaakt op basis van een matrix waarbij de oorspronkelijke typering en de realisatie tegen elkaar worden afgezet. In dit rapport wordt hierbij steeds uitgegaan van de relatieve prognoses. Opgemerkt dient echter te worden dat bij een dergelijke evaluatie gelijktijdig de voorspelkwaliteit van de prognoses als de wijze van typeren wordt geëvalueerd. Relatief slechte prognoses die getypeerd worden in kwalificaties die een breed interval vertegenwoordigen, kunnen toch heel bevredigend zijn geweest (Borghans, Van Eijs en De Grip, 1994). Omgekeerd zullen zeer nauwkeurige prognoses vaak een onjuiste typering krijgen als de kwalificaties gebaseerd zijn op extreem smalle intervallen.

\section{De vervangingsvraag tot 2006}

\subsection{Inleiding}

De vervangingsvraag is naast de uitbreidingsvraag een uitermate relevante bron van vraag naar nieuwkomers op de arbeidsmarkt. De vervangingsvraag heeft betrekking op de vraag op de arbeidsmarkt die ontstaat als gevolg van (tijdelijke) arbeidsmarktuittrede, mobiliteit tussen beroepsgroepen, of een verandering in de opleidingsachtergrond van werkenden. In paragraaf 3.2 wordt allereerst ingegaan op de methodiek die gehanteerd is bij het bepalen van de vervangingsvraagprognoses voor de vijfjaarsperiode van 2000 (basisjaar) tot 2006. Daarna wordt in paragraaf 3.3 nauwgezet ingegaan op de empirische evaluatie van de vervangingsvraagprognoses. 


\subsection{Prognosemethodiek}

De vervangingsvraag is naast de uitbreidingsvraag een belangrijke component van de baanopeningen per beroepsklasse of opleidingstype. Zelfs in beroepen waarbij sprake is van een krimpende werkgelegenheid kan er toch nog sprake zijn van vraag naar schoolverlaters en andere nieuwkomers, bijvoorbeeld vanwege het vertrek van oudere werknemers. De vervangingsvraag is sterk afhankelijk van de leeftijdsopbouw van de werkzame populatie naar beroep en opleiding. Beroepen met veel oudere werkenden kennen doorgaans een hogere arbeidsmarktuitstroom dan beroepen met veel jongeren. Hetzelfde geldt voor beroepen waarin relatief veel vrouwen werkzaam zijn. Vrouwen treden vaker (tijdelijk) uit op relatief jongere leeftijd om zorg- of huishoudelijke taken op zich te nemen (het zogeheten 'kinderdal').

Voor de prognoses van de vervangingsvraag tot 2006 werd gebruik gemaakt van de methodiek gebaseerd op Willems en De Grip (1993). De methodiek van Willems en De Grip (1993) behelst zowel een aanpassing van de definitie van de vervangingsvraag ten opzichte van de voorheen gebruikte uitstroom, als een verbeterde prognosetechniek. Een belangrijk aspect met betrekking tot de definitie van vervangingsvraag is dat alleen gekeken wordt naar het vertrek van werkenden voor zover hun plaatsen weer worden opgevuld. Dit impliceert namelijk dat bij een krimpende vraag de vervangingsvraag lager zal zijn dan simpelweg de uitstroom van werkenden.

Omdat de vervangingsvraag voortkomt uit stromen op de arbeidsmarkt, zouden voor het vaststellen van de vervangingsvraag het beste bruto stroomcijfers gehanteerd kunnen worden. Deze cijfers waren voor de vervangingsvraagprognose tot 2006 niet beschikbaar op een aggregatieniveau dat nodig is en daarom is gebruik gemaakt van de zogenaamde cohort-componenten-methode. In deze methodiek wordt op basis van een vergelijking van standcijfers tussen verschillende 
jaren een indicatie verkregen van de stromen die tussentijds plaats hebben gevonden (zie Willems en De Grip, 1993 en Cörvers et al., 2002). Door de standcijfers per geslacht op te splitsen in pseudocohorten naar leeftijd, kan per leeftijdscategorie de netto in- of uitstroom worden vastgesteld. De uitstroomcoëfficiënten die op basis van deze gegevens worden geschat over de voorbije analyseperiode, worden vervolgens geprojecteerd op de leeftijdsverdeling in het basisjaar, om zo een prognose te kunnen maken van de uitstroom in de komende jaren. Deze prognose wordt gecorrigeerd voor de verwachte veranderingen in de arbeidsparticipatie per geslacht/leeftijdscohort voor de gehele beroepsbevolking. Naast deze participatiecorrectie vindt ook een vergelijkbare correctie plaats voor de conjuncturele situatie in de analyseperiode. Beide correctiefactoren zijn voor alle beroepsgroepen en opleidingstypen gelijk. Deze aanpak is onveranderd gebleven ten opzichte van de eerdere prognoses.

De cohort-componenten-methode die wordt gebruikt kent een drietal mogelijke problemen. Ten eerste is er sprake van meetonzekerheid. Omdat de methode nu eenmaal gebaseerd is op de vergelijking van twee standcijfers, die door de opsplitsing in geslachts- en leeftijdsgroepen veelal betrekking hebben op kleine groepen, is de invloed van de steekproefonzekerheid zeer groot. Dit probleem kan op een drietal manieren worden ondervangen. De eenvoudigste aanpassing betreft een plausibiliteitstoets. Clements (1995) laat zien dat het oordeel van een deskundige vaak een gunstige invloed heeft bij onzekere prognosetechnieken. Werd vroeger besloten om de vervangingsvraagprognoses zo min mogelijk bij te stellen, mede omdat er toentertijd geen inzicht was in de onderliggende uitstroompatronen voor de verschillende geslachts- en leeftijdsgroepen voor een bepaald beroep of opleidingstype, bij de prognoses tot 2006 is daarentegen ingegrepen bij minder plausibele prognose-uitkomsten. Bij de prognoses tot 2006 is de plausibiliteit van de afzonderlijke parameters getoetst en zijn de uitkomsten dienovereenkomstig aangepast. Een tweede mogelijke aanpak van het probleem van de steekproefonzekerheid is het vergelijken van meerdere waarnemingsjaren, in plaats van de 
standcijfers van slechts twee jaren. Deze methode werd bij eerdere prognoses ook al gebruikt om meetfouten tegen elkaar weg te laten vallen. Een derde mogelijke aanpak is om in het econometrisch model expliciet met meetfouten rekening te houden. In Willems (1996) is een methode ontwikkeld die is gebaseerd op een random-coëfficiëntenmodel, dat naarmate een stroomcoëfficiënt minder nauwkeurig wordt gemeten, sterker terugvalt op de gemiddelde coëfficiënt voor de betreffende groep bij alle beroepsklassen of alle opleidingstypen. Dit houdt in dat wanneer een stroomcoëfficiënt voor een bepaalde beroepsklasse of opleidingstype te sterk afwijkt, deze wordt 'overruled' door een meer gematigde uitkomst van een overkoepelende groep beroepsklassen of opleidingstypen. Zo kan bijvoorbeeld een onbetrouwbare uitkomst voor de lassers en constructie medewerkers worden vervangen door de uitstroomcoëfficiënt van het (hogere) cluster technische, ambachts- en industrieberoepen.

Een tweede probleem bij het voorspellen van de vervangingsvraag betreft de samenhang tussen uitstroom en uitbreidingsvraag. Zoals al eerder werd aangestipt, kan krimpende werkgelegenheid gerealiseerd worden door een verhoogde uitstroom van zittend personeel of door een verlaagde instroom van nieuwkomers. Door de prognoses te baseren op vervangingsvraag wordt impliciet verondersteld dat de aanpassing bij een krimpende werkgelegenheid plaatsvindt door een verhoogde uitstroom van werkenden, waarvan nieuwkomers per saldo geen hinder ondervinden. In eerdere evaluatierapporten bleek deze aanpak namelijk dichter bij de werkelijkheid te liggen dan de omgekeerde veronderstelling dat krimp volledig ten koste gaat van nieuwkomers. Uit deze analyse bleek echter ook dat een gedeeltelijke correctie voor krimpende werkgelegenheid de prognoses verder zou kunnen verbeteren.

Een derde probleem, zoals eerder is opgemerkt, is dat per onderscheiden cohort alleen het saldo van in- en uitstroom wordt waargenomen. Met name bij beroepsgroepen of opleidingstypen waar wel veel sprake is van herintrede, kan door 20 
simultane in- en uitstroom in een bepaalde leeftijdsgroep deze netto-stroom de bruto-uitstroom sterk onderschatten. Dit probleem is inherent aan de beschikbare data. De enige oplossing is het nog verder opsplitsen van de onderscheiden groepen. Dit leidt echter tot een verhoging van het meetonzekerheidsprobleem. Belangrijke vooruitgang op dit punt kan verwacht worden als de panelgegevens uit de EBB worden gebruikt om de prognoses te maken.

\subsection{Empirische analyse van de vervangingsvraagprognoses naar beroep}

Bij de evaluatie van de vervangingsvraagprognoses doet zich het probleem voor dat cijfers over de feitelijke vervangingsvraag gedurende de periode 2000-2006 ontbreken. Daarom is deze feitelijke vervangingsvraag gereconstrueerd. Hierbij is gebruik gemaakt van dezelfde methodiek als bij de prognose, namelijk de zogenaamde netto-methode, waarbij gelijktijdige in- en uitstroom niet wordt waargenomen. Omdat voor de vervangingsvraag de SAB-prognose geen zinvolle referentie is, wordt evenals in voorgaande evaluatiestudies de gemiddelde voorspelde vervangingsvraag, uitgedrukt als percentage van de werkgelegenheid in 2000, als referentieprognose genomen.

Tabel 3.1 geeft een overzicht van de prognose, de realisatie en de voorspelfout per beroepsgroep. Tevens worden de referentieprognose en het verlies gepresenteerd. Uit de tabel blijkt dat de voorspelfout voor veel beroepsgroepen negatief is. Dit betekent dat de prognoses voor deze beroepsgroepen de vervangingsvraag overschatten. In meer detail, voor $61 \%$ van de beroepsgroepen wordt een overschatting gevonden. Gesommeerd over alle beroepsgroepen geldt dat de 'overall' prognose de totale 'werkelijke' vervangingsvraag (769.000) met ongeveer 284.000 personen overschat. Dit is hoger dan in de voorafgaande prognose tot 2002 (overschatting van 194.000 personen), maar is nog steeds beduidend lager dan de overschatting in de prognoses tot 1998 en 2000 (respectievelijk 440.000 en 575.000). De vijf beroepsgroepen met de grootste nominale overschatting van de vervangingsvraag zijn: Boekhouders en secretaressen, Receptionisten en administratieve 
employés, Chauffeurs, Verplegenden en doktersassistenten en Leraren basisonderwijs. De vervangingsvraag werd voor deze beroepsgroepen met minimaal 14.000 overschat. De prognoses voor de genoemde groepen tezamen resulteren in een voorspelfout van meer dan 130.000 , wat $46 \%$ van de totale overschatting vormt.

Tegenover deze overschattingen staan enkele beroepsgroepen waarvoor de vervangingsvraagprognoses tot 2006 een onderschatting waren. De voornaamste uitschieters, in absolute aantallen, zijn hier: Vakkenvullers, Verzorgend personeel, Verpleeghulpen en leerling-verpleegkundigen, en Systeemanalisten. Voor de Vakkenvullers wordt zelfs een onderschatting van meer dan 10.000 waargenomen. Voor de andere beroepsgroepen ligt de overschatting tussen de 3.400 en de 5.800 .

In totaal wordt er voor 41 beroepsgroepen een onderschatting waargenomen. Dit komt overeen met een onderschatting van 34\% van de 127 beroepsgroepen. Daarmee volgt deze prognose de trend die reeds in het evaluatierapport van Dupuy (2005) voor de prognoses tot 2002 is vastgesteld. Tot 1998 was sprake van een sterke daling van het aantal beroepsgroepen waarvoor de vervangingsvraag werd onderschat (van $90 \%$ in 1992 tot $15 \%$ in 1998). Vanaf 1998 nam de proportie echter weer toe van $20 \%$ in 2000 tot $25 \%$ in 2002 en nu $34 \%$ in 2006. Echter, de totale onderschatting over alle beroepsgroepen (78.000) is nu substantieel lager dan de sommatie van de overschatting over alle beroepsgroepen.

Een andere indicator die aangeeft hoe goed de prognoses sporen met de realisaties is het verlies. De grootste verliezen worden waargenomen voor Landbouwkundigen, Vakkenvullers, Agrarische hulparbeiders, Laboratorium-assistenten en Stewardessen. Opvallend hierbij is dat de verliezen het grootst zijn voor twee agrarische beroepen. Het grote verlies van de beroepsgroep Vakkenvullers werd eveneens waargenomen in het voorafgaande evaluatierapport. Een belangrijke factor die deze grote verliezen grotendeels bepaald is het kleine aantal werkenden in deze beroepsgroepen (met uitzondering van de Vakkenvullers). 
Het verlies is het laagst voor de beroepsgroepen: Activiteitenbegeleiders en medewerkers arbeidsbemiddeling, Grafisch productiepersoneel, Elektronisch ontwerpers en bedrijfshoofden, Verzekeringsagenten en Productieplanners. Het betreft hier een uiterst heterogene groep. 


\section{Tabel 3.1}

Verlies vervangingsvraagprognoses per beroepsgroep

\begin{tabular}{|c|c|c|c|c|c|}
\hline Beroepsgroep & Referentieprognose & Prognose & Realisatie & Voorspelfout & Verlies \\
\hline Leraar basisonderwijs & 22400 & 26400 & 12400 & -14100 & 0,0098 \\
\hline Docenten exacte, medische en verzorgende vakken (2e gr.) & 2800 & 5700 & 3200 & -2600 & 0,0201 \\
\hline Docenten exacte, medische en verzorgende vakken (1e gr.) & 2600 & 3600 & 4000 & 400 & 0,0004 \\
\hline Docenten landbouw en techniek (2e gr.) & 2800 & 4300 & 1900 & -2500 & 0,0198 \\
\hline Docenten landbouw en techniek (le gr.) & 400 & 1000 & 800 & -300 & 0,0121 \\
\hline Docenten economisch-administratieve vakken ( 2 e gr.) & 2100 & 2400 & 1200 & -1300 & 0,0103 \\
\hline Docenten economisch-administratieve vakken (1e gr.) & 700 & 1600 & 1100 & -600 & 0,0143 \\
\hline Docenten talen en expressie & 5800 & 9800 & 7100 & -2800 & 0,0056 \\
\hline Docenten letteren (1e gr.) & 4100 & 6400 & 3300 & -3200 & 0,0148 \\
\hline Docenten sociale vakken (2e gr.) & 2300 & 3100 & 5700 & 2600 & 0,0332 \\
\hline Docenten sociale vakken (1e gr.) & 1200 & 2500 & 1800 & -800 & 0,0099 \\
\hline Docenten $2 \mathrm{e}$ gr. zonder specialisatie & 1200 & 2300 & 2100 & -300 & 0,0010 \\
\hline Docent 1e gr. zonder specialisatie & 300 & 800 & 600 & -300 & 0,0201 \\
\hline Onderwijskundig medewerkers & 1500 & 600 & 2400 & 1800 & 0,0344 \\
\hline Onderwijskundigen en pedagogen & 2800 & 2900 & 1800 & -1200 & 0,0042 \\
\hline Rij-instructeurs & 1000 & 2200 & 2100 & -200 & 0,0007 \\
\hline Zweminstructeurs & 500 & 500 & 400 & -200 & 0,0023 \\
\hline Sportinstructeurs & 1600 & 1100 & 2200 & 1100 & 0,0113 \\
\hline Tolken, vertalers en schrijvers & 1800 & 2000 & 4000 & 2000 & 0,0284 \\
\hline Bibliotheekassistenten & 3700 & 6200 & 4000 & -2300 & 0,0098 \\
\hline Bibliothecarissen & 1700 & 1200 & 1100 & -200 & 0,0002 \\
\hline Grafisch ontwerpers & 1800 & 1600 & 2400 & 800 & 0,0042 \\
\hline Kunstenaars & 7700 & 6600 & 8900 & 2300 & 0,0022 \\
\hline Geestelijk verzorgers & 500 & & 800 & & \\
\hline Geestelijken & 900 & 1200 & 1400 & 200 & 0,0008 \\
\hline Journalisten & 2700 & 2600 & 2200 & -500 & 0,0008 \\
\hline Taalkundigen & 1500 & 1100 & 2900 & 1800 & 0,0348 \\
\hline Agrarische hulparbeiders & 1300 & 800 & 3500 & 2700 & 0,1061 \\
\hline
\end{tabular}




\begin{tabular}{|c|c|c|c|c|c|}
\hline Beroepsgroep & Referentieprognose & Prognose & Realisatie & Voorspelfout & Verlies \\
\hline Agrarische arbeiders & 17600 & 16400 & 8700 & -7800 & 0,0048 \\
\hline Agrarische vakkrachten & 1100 & 1500 & 1300 & -300 & 0,0014 \\
\hline Milieuhygiënisten en agrarisch vertegenwoordigers & 2000 & 2800 & 3200 & 400 & 0,0008 \\
\hline Landbouwkundigen & 300 & 300 & 1200 & 900 & 0,2575 \\
\hline Landbouwmachinebestuurders en vissers & 1400 & 1800 & 1900 & 100 & 0,0001 \\
\hline Agrarische bedrijfshoofden & 17100 & 21300 & 12000 & -9400 & 0,0073 \\
\hline Productiemedewerkers & 15200 & 12000 & 13100 & 1100 & 0,0001 \\
\hline Laboratorium-assistenten & 500 & 300 & 1200 & 900 & 0,0679 \\
\hline Laboranten & 1900 & 2300 & 3100 & 800 & 0,0043 \\
\hline Technisch analisten & 1800 & 1700 & 2200 & 500 & 0,0018 \\
\hline Natuurwetenschappers & 2600 & 2500 & 2700 & 200 & 0,0001 \\
\hline Conciërges & 4600 & 7300 & 5300 & -2100 & 0,0049 \\
\hline Hoofden technische dienst & 1900 & 3100 & 3000 & -200 & 0,0002 \\
\hline Werktuigbouwkundigen & 1100 & 1200 & 2500 & 1300 & 0,0356 \\
\hline Bouwvakkers & 28600 & 27600 & 15500 & -12200 & 0,0045 \\
\hline Aannemers en installateurs & 29600 & 27200 & 25500 & -1800 & 0,0001 \\
\hline Architecten en bouwkundig projectleiders & 7100 & 7100 & 7500 & 400 & 0,0001 \\
\hline Weg- en waterbouwkundigen & 3300 & 2000 & 5100 & 3100 & 0,0212 \\
\hline Weg- en waterbouwkundige arbeiders & 3200 & 3400 & 3700 & 300 & 0,0002 \\
\hline Weg- en waterbouwkundige vakkrachten & 5900 & 5700 & 1900 & -3900 & 0,0106 \\
\hline Weg- en waterbouwkundig ontwerpers en projectleiders & 1600 & 1800 & 1600 & -300 & 0,0004 \\
\hline Metaalarbeiders & 13700 & 14000 & 5400 & -8700 & 0,0099 \\
\hline Bankwerkers en lassers & 10600 & 8700 & 5100 & -3700 & 0,0030 \\
\hline Bedrijfshoofden metaalbewerking & 700 & 700 & 800 & 100 & 0,0001 \\
\hline Assembleurs & 4000 & 2900 & 1900 & -1100 & 0,0018 \\
\hline Monteurs & 31300 & 30500 & 22100 & -8500 & 0,0018 \\
\hline Werktuigbouwkundig ontwerpers en hoofden technische dienst & 4600 & 6000 & 3700 & -2400 & 0,0069 \\
\hline Elektronicamonteurs & 1900 & 1800 & 700 & -1200 & 0,0088 \\
\hline Monteurs en controleurs elektrotechnische producten & 2500 & 2600 & 1700 & -1000 & 0,0037 \\
\hline Elektromonteurs & 13100 & 13100 & 10600 & -2600 & 0,0009 \\
\hline
\end{tabular}




\begin{tabular}{|c|c|c|c|c|c|}
\hline Beroepsgroep & Referentieprognose & Prognose & Realisatie & Voorspelfout & Verlies \\
\hline Elektrotechnisch ontwerpers en bedrijfshoofden & 1600 & 1800 & 1800 & -100 & 0,0000 \\
\hline Elektrotechnici & 1300 & 1500 & 700 & -900 & 0,0114 \\
\hline Grafisch productiepersoneel & 3300 & 4300 & 4400 & 100 & 0,0000 \\
\hline Grafische vakkrachten & 5800 & 7000 & 2100 & -5000 & 0,0182 \\
\hline Mechanisch operators & 10500 & 12300 & 5900 & -6500 & 0,0094 \\
\hline Procesoperators & 8200 & 6500 & 8400 & 1900 & 0,0013 \\
\hline Procestechnologen & 1600 & 2700 & 3900 & 1200 & 0,0126 \\
\hline Materiaalkundigen & 2200 & 3100 & 2200 & -1000 & 0,0052 \\
\hline Confectie-arbeiders & 4100 & 7300 & 4500 & -2900 & 0,0123 \\
\hline Schoen- en kleermakers & 1000 & 600 & 1700 & 1100 & 0,0326 \\
\hline Laders en lossers & 17700 & 10700 & 9600 & -1200 & 0,0001 \\
\hline Chauffeurs & 38100 & 35600 & 17600 & -18100 & 0,0055 \\
\hline Schippers en conducteurs & 2900 & 3700 & 3400 & -400 & 0,0005 \\
\hline Vliegers, scheepskapiteins en leidinggevenden transport & 2500 & 3100 & 1600 & -1600 & 0,0095 \\
\hline Stewardessen & 1600 & 900 & 2900 & 2000 & 0,0435 \\
\hline Verpleeghulpen en leerling-verpleegkundigen & 5500 & 2300 & 7500 & 5200 & 0,0223 \\
\hline Verplegenden en doktersassistenten & 16400 & 23000 & 7200 & -15900 & 0,0231 \\
\hline Therapeuten en verpleegkundigen & 17000 & 24600 & 11600 & -13100 & 0,0145 \\
\hline Artsen & 10700 & 12400 & 6800 & -5700 & 0,0069 \\
\hline Apothekersassistenten en medisch laboranten & 6700 & 5100 & 3100 & -2100 & 0,0023 \\
\hline Medisch analisten & 3100 & 3100 & 4700 & 1600 & 0,0066 \\
\hline Apothekers & 1300 & 800 & 1400 & 600 & 0,0050 \\
\hline Afdelingshoofden zorginstelling & 1200 & 1400 & 2600 & 1200 & 0,0237 \\
\hline Kantoorhulpen, inpakkers en colporteurs & 10100 & 8800 & 7600 & -1300 & 0,0004 \\
\hline Ondersteunende administratieve hulpkrachten & 900 & 1500 & 1200 & -400 & 0,0046 \\
\hline Bedrijfshoofden & 9500 & 6500 & 6100 & -500 & 0,0001 \\
\hline Economen & 2700 & 1400 & 3400 & 2000 & 0,0137 \\
\hline Productieplanners & 9100 & 5200 & 5500 & 300 & 0,0000 \\
\hline Organisatie-adviseurs & 6600 & 4900 & 4500 & -500 & 0,0001 \\
\hline Organisatiedeskundigen & 3100 & 2200 & 2400 & 200 & 0,0001 \\
\hline
\end{tabular}




\begin{tabular}{|c|c|c|c|c|c|}
\hline Beroepsgroep & Referentieprognose & Prognose & Realisatie & Voorspelfout & Verlies \\
\hline Receptionisten en administratieve employés & 39200 & 50900 & 24600 & -26400 & 0,0111 \\
\hline Boekhouders en secretaresses & 70400 & 91400 & 35100 & -56400 & 0,0157 \\
\hline Assistent accountants & 12300 & 11000 & 9300 & -1800 & 0,0005 \\
\hline Accountants & 7200 & 3300 & 5300 & 2000 & 0,0019 \\
\hline Verzekeringsagenten & 3200 & 3300 & 3400 & 100 & 0,0000 \\
\hline Commercieel employés & 50000 & 49700 & 36700 & -13100 & 0,0017 \\
\hline Commercieel medewerkers & 36400 & 26600 & 21900 & -4800 & 0,0004 \\
\hline Technisch-commercieel employés & 2500 & 2500 & 2800 & 300 & 0,0003 \\
\hline Technisch-bedrijfskundig medewerkers & 1900 & 2400 & 3200 & 800 & 0,0041 \\
\hline Juridisch en fiscaal medewerkers & 5100 & 8100 & 4000 & -4200 & 0,0162 \\
\hline Juridisch, bestuurlijk medewerkers & 2700 & 4700 & 3000 & -1800 & 0,0106 \\
\hline Juristen & 9100 & 8600 & 4300 & -4400 & 0,0057 \\
\hline Administratieve transportemployés & 5200 & 5400 & 600 & -4900 & 0,0224 \\
\hline Leidinggevenden & 8800 & 9800 & 2700 & -7200 & 0,0164 \\
\hline Managers & 17600 & 16200 & 4200 & -12100 & 0,0116 \\
\hline Medisch secretaresses & 3700 & 2000 & 1600 & -500 & 0,0004 \\
\hline Programmeurs & 14000 & 6600 & 7700 & 1100 & 0,0001 \\
\hline Systeemanalisten & 19100 & 8400 & 13400 & 5000 & 0,0017 \\
\hline Informatici & 6300 & 1800 & 3300 & 1500 & 0,0013 \\
\hline Technisch systeemanalisten & 1700 & 1300 & 1600 & 300 & 0,0005 \\
\hline Activiteitenbegeleiders en medewerkers arbeidsbemiddeling & 12100 & 7500 & 7500 & -100 & 0,0000 \\
\hline Medewerkers sociaal-cultureel werk en personeel en arbeid & 15600 & 11600 & 7100 & -4600 & 0,0021 \\
\hline Hoofden sociaal-cultureel werk en personeel en arbeid & 1500 & 1900 & 400 & -1600 & 0,0304 \\
\hline Sociaal-wetenschappelijk medewerkers & 1800 & 2500 & 600 & -2000 & 0,0300 \\
\hline Sociaal-wetenschappelijk onderzoekers & 4300 & 3500 & 2500 & -1100 & 0,0014 \\
\hline Vakkenvullers & 3900 & 1200 & 12100 & 10900 & 0,1934 \\
\hline Interieurverzorgers & 25200 & 25900 & 18700 & -7300 & 0,0021 \\
\hline Verkopers & 44300 & 36800 & 40300 & 3500 & 0,0001 \\
\hline Winkeliers & 21900 & 24700 & 18000 & -6800 & 0,0024 \\
\hline Hulpkrachten horeca en verzorging & 24800 & 22000 & 18900 & -3200 & 0,0004 \\
\hline
\end{tabular}




\begin{tabular}{|c|c|c|c|c|c|}
\hline Beroepsgroep & Referentieprognose & Prognose & Realisatie & Voorspelfout & Verlies \\
\hline Ziekenverzorgenden & 11000 & 13800 & 2300 & -11600 & 0,0272 \\
\hline Verzorgend personeel & 30200 & 21700 & 27500 & 5800 & 0,0009 \\
\hline Café- en snackbarhouders & 2400 & 3000 & 2200 & -900 & 0,0034 \\
\hline Bedrijfshoofden horeca & 8000 & 9600 & 3200 & -6500 & 0,0161 \\
\hline Bakkers en slagers & 2000 & 2400 & 2800 & 400 & 0,0007 \\
\hline Aspirant politieagenten, soldaten en beveiligingshulpkrachten & 7600 & 6300 & 9300 & 3000 & 0,0039 \\
\hline Politieagenten, onderofficieren en beveiligingsemployés & 6900 & 7600 & 5100 & -2600 & 0,0035 \\
\hline Politie-inspecteurs en officieren & 1300 & 900 & 1500 & 600 & 0,0043 \\
\hline Brandweerlieden & 1000 & 1600 & 900 & -800 & 0,0153 \\
\hline
\end{tabular}


Tabel 3.2

Totaaloverzicht voorspelkwaliteit vervangingsvraagprognoses per beroepsgroep

\begin{tabular}{|c|c|c|c|}
\hline Methode & $\begin{array}{l}\text { Gem. verlies } \\
\text { prognose }\end{array}$ & $\begin{array}{l}\text { Gem. verlies } \\
\text { referentie }\end{array}$ & Score \\
\hline \multicolumn{4}{|l|}{ Prognoses tot 2006} \\
\hline \multicolumn{4}{|l|}{ Vervangingsvraag } \\
\hline Absoluut & 0,0070 & 0,0049 & 1,41 \\
\hline Relatief & 0,0042 & 0,0031 & 1,33 \\
\hline \multirow{2}{*}{$\begin{array}{l}\text { Absoluut groeiberoepen } \\
\text { Relatief groeiberoepen }\end{array}$} & 0,0024 & 0,0016 & 1,52 \\
\hline & 0,0019 & 0,0013 & 1,42 \\
\hline \multirow{2}{*}{$\begin{array}{l}\text { Absoluut krimpberoepen } \\
\text { Relatief krimpberoepen }\end{array}$} & 0,0045 & 0,0033 & 1,36 \\
\hline & 0,0023 & 0,0018 & 1,27 \\
\hline \multicolumn{4}{|l|}{ Prognoses tot 2002} \\
\hline \multicolumn{4}{|l|}{ Vervangingsvraag } \\
\hline Absoluut & 0,0039 & 0,0031 & 1,26 \\
\hline Relatief & 0,0024 & 0,0022 & 1,10 \\
\hline \multicolumn{4}{|l|}{ Prognoses tot 2000} \\
\hline \multicolumn{4}{|l|}{ Vervangingsvraag } \\
\hline Absoluut & 0,0107 & 0,0090 & 1,19 \\
\hline Relatief & 0,0026 & 0,0021 & 1,23 \\
\hline
\end{tabular}

Tabel 3.2 toont de algehele voorspelkwaliteit van de vervangingsvraagprognoses tot 2006. De tabel laat zien dat het gemiddelde verlies van de absolute prognoses wat is toegenomen ten opzichte van het verlies in de prognoses tot 2002. Het gemiddelde verlies van de absolute prognoses is echter nog steeds beduidend lager dan die in de prognoses tot 2000. Voor de relatieve prognoses is er een verslechtering opgetreden. De score van de prognoses geeft aan dat de referentieprognoses voor de absolute en de relatieve vervangingsvraag tot 2006 beter waren dan de werkelijke prognoses (scores van 1,41 en 1,33). Hoewel de scores iets zijn verslechterd liggen de waarden van de scores niet ver van de gevonden waarden in de voorgaande evaluatierapporten.

De tabel laat verder zien dat voorspelkwaliteit van de vervangingsvraagpronoses verschilt tussen de groei- en de krimpberoepen. Het gemiddeld verlies van de 
aboslute prognoses is groter voor de krimpberoepen dan voor de groeiberoepen $(0,0045$ ten opzichte van 0,0024$)$. Het verschil in het gemiddeld verlies van de relatieve prognoses is veel kleiner voor de relatieve dan voor de absolute prognoses. Het gemiddelde verlies van de krimpberoepen is daar 0,0023 , terwijl het verlies voor de groeiberoepen 0,0019 is. De scores voor de prognoses geven aan dat de referentieprognoses voor zowel de groei- als de krimpberoepen beter waren dan de werkelijke prognoses. De scores voor de groeiberoepen waren iets slechter dan de scores voor de krimpberoepen.

\section{Verklaring van voorspelfouten}

De eerste vraag is wat de bron van de absolute overschatting van de vervangingsvraag naar beroep is. Een mogelijke verklaring zou kunnen zijn dat de stijging van de participatiegraad is onderschat op het moment dat vervangingsvraagprognoses werden samengesteld. Een hogere participatiegraad leidt tot minder uitstroom en en een lagere vervangingsvraag. Als de participatiegraad tussen 2000 en 2006 meer zou zijn gestegen dan voorzien, dan zou als gevolg daarvan de vervangingsvraag lager uitvallen dan voorzien, zoals bij deze evaluatie is gebleken. Als we kijken naar de prognoses van de (bruto) participatiegraad van het Centraal Planbureau (CPB) in 2000, en we vergelijken deze met de feitelijke ontwikkeling tot 2006, dan blijkt echter dat het $\mathrm{CPB}$ de stijging van de participatiegraad eerder heeft over- dan onderschat.

Dit laatste brengt ons echter op een tweede mogelijke verklaring. De overschatting van de participatiegraad door het $\mathrm{CPB}$ heeft o.a. te maken met de terugval in de conjunctuur, waardoor de algehele vraag op de arbeidsmarkt (werkgelegenheid en vacatures) sterk terugviel in de jaren 2003 en 2004. In 2005 verliep het herstel nog moeizaam, waardoor ook de participatiegraad nauwelijks toenam. Belangrijk is hierbij dat we in deze jaren veel uitstroom zien die niet vervangen wordt. Dit wordt bijvoorbeeld geconstateerd in De arbeidsmarkt naar opleiding en beroep tot 2012 
(ROA, 2007, bij tabel 1.1). Bij de berekening van de realisatie van de vervangingsvraag betekent dit dat er er veel beroepsgroepen zijn die tussen 2000 en 2006 zijn gekrompen, onder andere doordat de uitstroom niet werd vervangen (denk aan natuurlijke afvloeïng). De realisatie van de vervangingsvraag die in de voorliggende evaluatiestudie wordt gebruikt is daardoor lager uitgevallen dan de prognose. Tussen 2005 en 2008 is de werkgelegenheid echter sterk gegroeid waardoor mogelijk de daadwerkelijke vervanging van uitgestroomd personeel plaats zal hebben gehad in de jaren na 2005.

Om meer inzicht te verkrijgen in de kwaliteit van de voorspellingen is getracht de voorspelfout in de vervangingsvraag te relateren aan enkele verklarende variabelen. Het resultaat is weergegeven in tabel 3.3. De parameter voor het schaaleffect is kleiner dan één, hetgeen impliceert dat grote beroepsgroepen in aantallen slechter, maar in procenten beter voorspeld worden dan de kleine beroepsgroepen. Wanneer deze resultaten vergeleken worden met de voorgaande evaluatie, dan blijkt het schaaleffect te zijn afgenomen (van 0,95 naar 0,69). De coefficient van de GiniHirschmann-spreidingsindex van beroepgroepen over bedrijfssectoren is negatief maar niet significant.

\section{Tabel 3.3}

Verklaring van voorspelfouten in de relatieve vervangingsvraagprognoses per beroepsgroep (relatief)

$\begin{array}{lcc}\text { Variabele } & \text { Parameter } & \text { T-waarde } \\ \text { Constante } & 0,22 & 0,23^{* *} \\ \text { Schaal } & 0,69 & 7,47^{* *} \\ \text { Spreidingsindicator over sectoren } & -0,03 & -0,86 \\ \text { Onderschattingsscoëfficiënt } & 0,00 & 0,00 \\ \text { Conjunctuur } & -0,22 & -0,23\end{array}$

* significant bij betrouwbaarheid van 90\%

** significant bij betrouwbaarheid van $95 \%$

Tevens is in bovenstaande tabel weergeven in hoeverre er sprake is van over- of onderschatting van de waargenomen veranderingen. Omdat we ervan uitgaan dat 
bij de vervangingsvraag de referentieprognose niet gelijk is aan de situatie in het verleden (Same As Before), wordt in dit geval de onder- of overschatting van afwijkingen van het gemiddelde geanalyseerd. De onderschattingscoëfficiënt bedraagt 0,0001 . Dit is aanzienlijk kleiner dan de onderschattingscoëfficiënt in de vorige evaluatie $(-0,61$, zie Dupuy, 2005), ondanks het feit dat absoluut gezien sprake is van een grotere overschatting van de vervangingsvraag. Het is hierbij relevant om op te merken dat hier wordt gekeken naar de relatieve vervangingsvraagprognose uitgedrukt in aantal personen, welke is herschaald voor de algehele overschatting in personen. Een over- of onderschatting in de absolute prognoses ten opzichte van de feitelijke veranderingen kan veroorzaakt worden door een te hoge of te lage gemiddelde prognose van de veranderingen. Als relatieve prognoses worden geanalyseerd is er gecorrigeerd voor het totale verschil tussen de prognose en de realisatie van de vervangingsvraag. In dat geval betekent een overschatting van veranderingen dat de voorspelde groei gemiddeld lager uitviel dan verwacht, terwijl tegelijkertijd ook de voorspelde krimp minder negatief uitviel dan voorzien. De onderschattingscoëfficiënt van nagenoeg 0 in tabel 3.3 impliceert dat er geen systematische onder- of overschatting meer is van veranderingen (zie paragraaf 2.3) van de relatieve prognose ten opzichte van de relatieve referentieprognose (het gemiddelde vervangingsvraag). De coëfficient van de conjunctuurindicator is niet significant.

\section{Kwalitatieve typeringen}

Bij de vervangingsvraag per beroepsgroep is een kwalitatieve typering gemaakt. De indeling van de kwalitatieve typeringen is als volgt:

$\begin{array}{rll} & \text { VBG } \leq 10 \% & \text { erg laag } \\ 10 \%<\text { VBG } & \leq 13 \% & \text { laag } \\ 13 \%<\text { VBG } & \leq 19 \% & \text { gemiddeld } \\ 19 \%<\text { VBG } & \leq 24 \% & \text { hoog } \\ 24 \%<\text { VBG } & & \text { erg hoog }\end{array}$

waarbij VBG staat voor vervangingsvraag per beroepsgroep. 
Tabel 3.4 toont in hoeverre de kwalitatieve typering van de relatieve voorspelling overeenkomt met de gerealiseerde typering. Uit de tabel blijkt dat voor 34 van de 126 beroepsgroepen (27\%) de voorspelde typering overeenkomt met de realisatie, terwijl voor 45 beroepsgroepen geldt dat de voorspelde kwalitatieve typering één categorie te hoog of te laag is. Dit betekent dat er in totaal in $63 \%$ van de beroepsgroepen een geheel of bijna juiste typering gemaakt is. Dit percentage is lager dan het percentage van de vervangingsvraagprognoses voor 2002 die in $80 \%$ van de gevallen geheel of bijna juist bleken te zijn. Er is met name een sterke toename van beroepsgroepen die de typering 'erg laag' kregen in de prognose, terwijl in de realisatie deze beroepsgroepen een erg hoge vervangingsvraag bleken te hebben. Deze extreme voorspelfout komt relatief vaak voor bij beroepsgroepen met kleine aantallen werkenden.

Tabel 3.4

Typeringen van de vervangingsvraag per beroepsgroep (relatief)

\begin{tabular}{|c|c|c|c|c|c|c|}
\hline \multirow[b]{2}{*}{ Prognose } & \multicolumn{6}{|c|}{ Realisatie } \\
\hline & erg laag & laag & gemiddeld & hoog & erg hoog & totaal \\
\hline Erg laag & 23 & 18 & 16 & 7 & 10 & 74 \\
\hline Laag & 13 & 4 & 5 & 4 & 7 & 33 \\
\hline Gemiddeld & 0 & 3 & 6 & 2 & 3 & 14 \\
\hline Hoog & 0 & 0 & 0 & 0 & 4 & 4 \\
\hline Erg hoog & 0 & 0 & 0 & 0 & 1 & 1 \\
\hline Totaal & 36 & 25 & 27 & 13 & 25 & 126 \\
\hline
\end{tabular}

\section{Conclusies}

Uit de evaluatie van de vervangingsvraagprognoses per beroepsgroep kan de conclusie worden getrokken dat de kwaliteit van de vervangingsvraagprognoses over het algemeen achteruit is gegaan. Tevens blijkt de referentieprognose (de gemiddelde prognose van de vervangingsvraag) zowel absoluut als negatief gezien een betere voorspeller te zijn van de vervangingsvraag dan de werkelijke prognose. Wellicht dat de sterke algehele daling van de werkgelegenheid in de prognoseperiode en daarmee samenhangend de grote uitstroom in de verschillende 
segmenten van de arbeidsmarkt anders heeft uitgepakt, waardoor het voorspellen van de vervangingsvraag per beroepsgroep een moeilijke opgave was. Een pluspunt is dat de relatieve prognoses van de vervangingsvraag niet duiden op een systematische over- of onderschatting.

\subsection{Empirische evaluatie van de vervangingsvraagprognoses naar opleiding}

In Tabel 3.5 wordt een overzicht gegeven van de voorspelfouten per opleidingstype. De tabel laat zien dat er - evenals bij de vervangingsvraag per beroepsgroep - over het algemeen sprake is van een overschatting van de vervangingsvraag. Over alle opleidingen is de vervangingsvraag met ruim 605.000 overschat. Voor 79 van de 104 geëvalueerde opleidingstypen geldt dat de prognose de gerealiseerde vervangingsvraag overtreft. De grootste absolute overschatting vinden we bij Basisonderwijs, VMBO theorie, $M B O$ administratie en logistiek, $V M B O$ (uiterlijke) verzorging en $M B O$ Handel. Net zoals in de voorgaande evaluaties, zijn al deze opleidingstypen van een laag of middelbaar niveau. De grootste gemiddelde voorspelfout treedt op bij het opleidingstype Basisonderwijs (154.900). Dit betekent dat ruim 26\% van de totale voorspelfout wordt veroorzaakt door het verlies bij dit opleidingstype. Het is derhalve ook weinig verrassend dat het grootste verlies wordt gemeten voor het opleidingstype Basisonderwijs. 


\section{Tabel 3.5}

Verlies vervangingsvraagprognoses per opleidingstype

\begin{tabular}{|c|c|c|c|c|c|}
\hline Opleidingstype & Referentieprognose & Prognose & Realisatie & Voorspelfout & Verlies \\
\hline Basisonderwijs & 98600 & 172300 & 17400 & -154900 & 0,1065 \\
\hline VMBO theorie & 109500 & 103900 & 61900 & -42100 & 0,0064 \\
\hline VMBO landbouw en natuurlijke omgeving & 12000 & 5700 & 9800 & 4100 & 0,0051 \\
\hline VMBO bouwtechniek & 26300 & 22300 & 8400 & -14000 & 0,0122 \\
\hline VMBO installatietechniek & 2400 & 1600 & 1500 & -200 & 0,0001 \\
\hline \multicolumn{6}{|l|}{ VMBO mechanische techniek\& } \\
\hline VMBO metaal: mechanische techniek & 25200 & 26500 & 3600 & -23000 & 0,0358 \\
\hline VMBO fijnmechanische techniek & 800 & 900 & 200 & -800 & 0,0478 \\
\hline VMBO voertuigentechniek & 8700 & 8000 & 5400 & -2700 & 0,0040 \\
\hline VMBO elektrotechniek & 10500 & 9700 & 5000 & -4800 & 0,0091 \\
\hline VMBO grafische techniek & 1500 & 1200 & 1300 & 100 & 0,0002 \\
\hline VMBO brood en banket & 2400 & 1500 & 2500 & 1000 & 0,0068 \\
\hline VMBO transport en logistiek & 3900 & 5500 & 2200 & -3400 & 0,0320 \\
\hline VMBO administratie,handel en mode & 25400 & 19000 & 17600 & -1500 & 0,0001 \\
\hline \multicolumn{6}{|l|}{ VMBO consumptief en } \\
\hline levensmiddelentechniek & 5800 & 17200 & 4200 & -13100 & 0,2236 \\
\hline VMBO (uiterlijke) verzorging & 37200 & 40800 & 13000 & -27900 & 0,0242 \\
\hline VMBO beveiliging & 1600 & 4000 & 2300 & -1800 & 0,0576 \\
\hline HAVO/VWO & 122400 & 95600 & 78700 & -17000 & 0,0008 \\
\hline MBO voeding, natuur en milieu & 17100 & 14600 & 5100 & -9600 & 0,0136 \\
\hline \multicolumn{6}{|l|}{ MBO groene ruimte\& } \\
\hline MBO milieu en groene ruimte & 5200 & 1800 & 2200 & 400 & 0,0002 \\
\hline MBO laboratorium & 6600 & 2800 & 1800 & -1100 & 0,0012 \\
\hline MBO bouw & 31400 & 28200 & 21900 & -6400 & 0,0018 \\
\hline
\end{tabular}




\begin{tabular}{|c|c|c|c|c|c|}
\hline Opleidingstype & Referentieprognose & Prognose & Realisatie & Voorspelfout & Verlies \\
\hline MBO grond-, weg- en waterbouw & 6100 & 2800 & 5200 & 2400 & 0,0065 \\
\hline MBO installatietechniek & 5300 & 3900 & 2600 & -1400 & 0,0026 \\
\hline MBO werktuigbouw en mechanische techniek & 29500 & 32400 & 15100 & -17400 & 0,0149 \\
\hline MBO fijnmechanische techniek & 3000 & 3500 & 3000 & -600 & 0,0017 \\
\hline MBO motorvoertuigentechniek en tweewielers & 15100 & 12800 & 12600 & -300 & 0,0000 \\
\hline MBO vliegtuigtechniek & 1100 & 900 & 1100 & 200 & 0,0004 \\
\hline MBO operationele techniek & 1500 & 1300 & 600 & -800 & 0,0137 \\
\hline MBO elektrotechniek & 34500 & 32800 & 17900 & -15000 & 0,0081 \\
\hline MBO grafische techniek & 7500 & 9200 & 5800 & -3500 & 0,0095 \\
\hline MBO procestechniek & 4100 & 2400 & 1400 & -1100 & 0,0026 \\
\hline MBO brood en banket & 3300 & 2900 & 1000 & -2000 & 0,0152 \\
\hline MBO levensmiddelentechniek/ vleesverwerking & 4600 & 3700 & 3700 & -100 & 0,0000 \\
\hline MBO vervoer & 8200 & 12900 & 5500 & -7500 & 0,0354 \\
\hline MBO dokters-, tandarts- en dierenartsassistent & 5800 & 4100 & 3100 & -1100 & 0,0014 \\
\hline MBO apothekersassistent & 4100 & 4600 & 2600 & -2100 & 0,0114 \\
\hline MBO verpleging & 16500 & 31000 & 8100 & -23000 & 0,0838 \\
\hline MBO gezondheidstechniek & 1200 & 1100 & 1600 & 500 & 0,0062 \\
\hline MBO sociaal-pedagogisch en welzijn & 23700 & 16300 & 14100 & -2300 & 0,0004 \\
\hline MBO verzorging & 41400 & 41400 & 20500 & -21000 & 0,0111 \\
\hline MBO uiterlijke verzorging & 12300 & 9500 & 9800 & 300 & 0,0000 \\
\hline MBO horeca & 12500 & 13200 & 2300 & -11000 & 0,0331 \\
\hline MBO beweging en therapie & 4600 & 5400 & 3300 & -2200 & 0,0100 \\
\hline MBO administratie en logistiek & 56100 & 61700 & 25100 & -36700 & 0,0184 \\
\hline MBO handel & 40700 & 52700 & 25900 & -26900 & 0,0188 \\
\hline MBO secretariaat & 19600 & 16900 & 11500 & -5500 & 0,0033 \\
\hline MBO toerisme en recreatie & 5200 & 8400 & 5100 & -3400 & 0,0182 \\
\hline
\end{tabular}




\begin{tabular}{|c|c|c|c|c|c|}
\hline Opleidingstype & Referentieprognose & Prognose & Realisatie & Voorspelfout & Verlies \\
\hline MBO facilitaire dienstverlening & 21000 & 12400 & 3000 & -9500 & 0,0087 \\
\hline MBO ICT & 5300 & 7800 & 4300 & -3600 & 0,0197 \\
\hline MBO geld, bank en belastingen & 1800 & 7100 & 0 & -7100 & 0,6832 \\
\hline MBO verzekeringswezen & 2600 & 5700 & 1400 & -4400 & 0,1231 \\
\hline MBO openbare orde en veiligheid & 14000 & 22700 & 8200 & -14600 & 0,0472 \\
\hline HBO lerarenopleiding basisonderwijs & 37400 & 35100 & 27600 & -7600 & 0,0018 \\
\hline HBO lerarenopleiding talen & 6200 & 8800 & 3200 & -5700 & 0,0369 \\
\hline HBO lerarenopleiding natuur en techniek & 5900 & 7000 & 3700 & -3400 & 0,0143 \\
\hline HBO lerarenopleiding economie en maatschappij & 6300 & 10700 & 5300 & -5500 & 0,0326 \\
\hline HBO lerarenopleiding lichamelijke opvoeding & 3100 & 2500 & 2800 & 300 & 0,0004 \\
\hline HBO lerarenopleiding medisch en verzorging & 2900 & 2900 & 1700 & -1300 & 0,0081 \\
\hline HBO lerarenopleiding expressie & 6400 & 8400 & 6700 & -1800 & 0,0031 \\
\hline HBO tolk en vertaler & 2000 & 1000 & 2400 & 1400 & 0,0231 \\
\hline HBO landbouw en veeteelt & 2100 & 400 & 800 & 400 & 0,0016 \\
\hline HBO milieukunde en levensmiddelentechnologie & 3900 & 3000 & 1500 & -1600 & 0,0076 \\
\hline HBO laboratorium & 7400 & 6700 & 6000 & -800 & 0,0004 \\
\hline HBO bouwkunde & 4400 & 3900 & 3600 & -400 & 0,0002 \\
\hline HBO civiele techniek & 4500 & 2500 & 2700 & 200 & 0,0001 \\
\hline HBO werktuigbouwkunde & 9400 & 6900 & 9300 & 2400 & 0,0027 \\
\hline HBO elektrotechniek & 7900 & 9700 & 3800 & -6000 & 0,0246 \\
\hline HBO informatica & 7200 & 5200 & 2800 & -2500 & 0,0049 \\
\hline HBO chemische technologie & 1900 & 1600 & 1000 & -700 & 0,0062 \\
\hline HBO vervoer en logistiek & 4700 & 4800 & 2300 & -2600 & 0,0130 \\
\hline HBO verpleegkunde & 11400 & 8700 & 4700 & -4100 & 0,0054 \\
\hline HBO (fysio)therapie & 10000 & 11300 & 9400 & -2000 & 0,0016 \\
\hline HBO voeding & 1100 & 400 & 1300 & 900 & 0,0284 \\
\hline
\end{tabular}




\begin{tabular}{|c|c|c|c|c|c|}
\hline Opleidingstype & Referentieprognose & Prognose & Realisatie & Voorspelfout & Verlies \\
\hline HBO radiologie & 2600 & 800 & 2400 & 1600 & 0,0169 \\
\hline HBO accountancy en bedrijfseconomie & 13500 & 10100 & 4900 & -5300 & 0,0065 \\
\hline HBO commerciële economie & 11300 & 6200 & 1800 & -4500 & 0,0066 \\
\hline HBO toerisme en recreatie & 2100 & 900 & 900 & -100 & 0,0001 \\
\hline HBO recht en bestuur & 3800 & 4100 & 2400 & -1800 & 0,0097 \\
\hline HBO secretariaat & 1100 & 7600 & 900 & -6800 & 1,7355 \\
\hline HBO bedrijfskunde & 16700 & 8600 & 1300 & -7400 & 0,0084 \\
\hline HBO communicatie en journalistiek & 5100 & 2400 & 7300 & 4900 & 0,0389 \\
\hline HBO maatschappelijk werk en hulpverlening & 17500 & 21500 & 15300 & -6300 & 0,0056 \\
\hline HBO personeel en arbeid & 5800 & 3400 & 3600 & 200 & 0,0000 \\
\hline HBO bibliotheek en documentatie & 2900 & 3000 & 2900 & -200 & 0,0001 \\
\hline HBO uitvoerende en beeldende kunsten & 11300 & 11200 & 8000 & -3300 & 0,0037 \\
\hline HBO openbare orde en veiligheid & 1000 & 1900 & 1000 & -1000 & 0,0473 \\
\hline WO letteren & 12100 & 6300 & 7100 & 800 & 0,0002 \\
\hline WO theologie & 2400 & 2200 & 1400 & -900 & 0,0059 \\
\hline WO landbouw en milieukunde & 2600 & 700 & 1600 & 900 & 0,0051 \\
\hline WO wiskunde en natuurwetenschappen & 15600 & 9600 & 8400 & -1300 & 0,0003 \\
\hline WO bouwkunde & 2900 & 1600 & 4400 & 2800 & 0,0378 \\
\hline WO civiele techniek & 2200 & 1200 & 1200 & -100 & 0,0001 \\
\hline WO werktuigbouwkunde & 2800 & 1700 & 3100 & 1400 & 0,0107 \\
\hline WO elektrotechniek & 2500 & 1700 & 2200 & 500 & 0,0019 \\
\hline WO informatica en bestuurlijke informatiekunde & 2500 & 300 & 3100 & 2800 & 0,0515 \\
\hline WO (dier)geneeskunde & 11200 & 9200 & 8300 & -1000 & 0,0003 \\
\hline WO tandheelkunde & 1600 & 1000 & 1400 & 400 & 0,0023 \\
\hline WO farmacie en medische biologie & 2100 & 700 & 2300 & 1600 & 0,0246 \\
\hline WO econom(etr)ie & 9800 & 5200 & 7500 & 2300 & 0,0022 \\
\hline
\end{tabular}


Opleidingstype

WO bedrijfskunde

WO accountancy en belastingen

WO rechten en bestuurskunde

WO sociale wetenschappen

WO kunstwetenschappen
Referentieprognose

7300
5100

15300

20700

1700
Prognose

2500

2700

9700

15900

600
Realisatie

2500

1400

12100

7400

800
Voorspelfout

$-100$

$-1400$

2400

$-8600$

200

0,0030

0,0010

0,0073

0,0003 
Tabel 3.6 geeft een overzicht van het gemiddelde verlies van de prognoses van de vervangingsvraag per opleidingstype. Evenals bij de vervangingsvraagprognoses per beroepsgroep het geval was, geldt ook nu dat de absolute prognoses zijn verslechterd ten opzichte van de prognoses tot 2002. Hetzelfde geldt voor de relatieve prognoses. De scores van zowel de absolute als de relatieve vervangingsvraag zijn minder goed dan voorheen. Dit betekent dat de referentieprognose beter is gaan voorspellen dan de werkelijke prognose. Voor de absolute prognoses is de score 1,84, voor de relatieve prognoses is de score 2,34. Blijkbaar levert de gehanteerde methodiek gemiddeld genomen een relatief goede prognose op, maar blijft het moeilijk om de opleidingsspecifieke verschillen goed te voorspellen.

Daarnaast blijkt uit de tabel dat de vervangingsvraagprognoses vooral voor de krimpende opleidingstypen slechter zijn voorspeld. Het gemiddeld verlies van de absolute prognose voor de krimpende opleidingstypen is 0,0156 terwijl deze voor de groeiende opleidingstypen slechts 0,0054 is. Het gemiddeld verlies van de relatieve prognose is eveneens beduidend hoger voor de krimpende opleidingstypen. Dit is opvallend aangezien het aantal krimpende opleidingstypen (56) niet veel groter is dan het aantal groeiende opleidingstypen (48). Het grote verschil in het gemiddeld verlies kan derhalve niet worden verklaard door het aantal krimpende opleidingstypen. Uit de scores blijkt dat de referentieprognose voor beide groepen opleidingstypen beter presteert dan de prognoses (zowel absoluut als relatief). Echter, de scores laten ook zien dat de prognose ten opzichte van de referentieprognose minder slecht voorspelt voor de groeiende opleidingstypen dan voor de krimpende opleidingstypen. 
Tabel 3.6

Totaaloverzicht voorspelkwaliteit vervangingsvraagprognoses per opleidingstype

\begin{tabular}{|c|c|c|c|}
\hline & $\begin{array}{l}\text { Gem. verlies } \\
\text { prognose }\end{array}$ & $\begin{array}{l}\text { Gem. verlies } \\
\text { referentie }\end{array}$ & Score \\
\hline \multicolumn{4}{|l|}{ Prognoses tot 2006} \\
\hline \multicolumn{4}{|l|}{ Vervangingsvraag } \\
\hline Absoluut & 0,0210 & 0,0114 & 1,84 \\
\hline Relatief & 0,0056 & 0,0024 & 2,34 \\
\hline \multirow{2}{*}{$\begin{array}{l}\text { Absoluut, groeiende opl.typen } \\
\text { Relatief groeiende opl.typen }\end{array}$} & 0,0054 & 0,0040 & 1,35 \\
\hline & 0,0017 & 0,0009 & 1,90 \\
\hline Absoluut krimpende opl.typen & 0,0156 & 0,0074 & 2,11 \\
\hline Relatief krimpende opl.typen & 0,0040 & 0,0015 & 2,59 \\
\hline \multicolumn{4}{|l|}{ Prognoses tot 2002} \\
\hline \multicolumn{4}{|l|}{ Vervangingsvraag } \\
\hline Absoluut & 0,0039 & 0,0040 & 0,98 \\
\hline Relatief & 0,0032 & 0,0035 & 0,91 \\
\hline \multicolumn{4}{|l|}{ Prognoses tot 2000} \\
\hline \multicolumn{4}{|l|}{ Vervangingsvraag } \\
\hline Absoluut & 0,0043 & 0,0023 & 1,85 \\
\hline Relatief & 0,0022 & 0,0015 & 1,37 \\
\hline
\end{tabular}

\section{Verklaring van voorspelfouten}

Zoals hierboven is gebleken, is de vervangingsvraag naar opleiding nog sterker overschat dan de vervangingsvraag naar beroep. Ook hier geldt dat de slechte conjuncturele situatie op de arbeidsmarkt een grote invloed kan hebben gehad, omdat er veel uitstroom heeft plaatsgevonden die niet is vervangen (zie verder de discussie bij de beroepsgroepen).

Tabel 3.7 geeft een beeld van de verklaringskracht van enkele mogelijke oorzaken van de relatieve voorspelfout van de vervangingsvraagprognoses per opleidingstype. Net als bij de overige onderdelen van de prognoses is de schaalparameter kleiner dan één. Dit betekent dat grotere opleidingstypen relatief slechter voorspeld zijn dan kleinere opleidingen, maar dat de prognoses voor de grotere opleidingstypen accurater zijn in termen van percentages. Dit werd eveneens waargenomen voor de vervangingsvraagprognoses per beroepsgroep. De schaalparameter is overigens iets 
kleiner dan bij de prognoses voor 2002. Afgezien van de constante, blijken de andere variabelen die in de vergelijking opgenomen zijn, geen significante invloed op de voorspelfout te hebben. Dit geldt zowel voor de twee spreidingsindicatoren als voor het percentage werkzame vrouwen met de betreffende opleidingsachtergrond. Dit spoort met de uitkomsten in eerdere evaluatierapporten. In tegenstelling tot de voorafgaande evaluaties is de onderschattingscoefficient klein en niet significant.

\section{Tabel 3.7}

Verklaring van voorspelfouten in de vervangingsvraagprognoses per opleidingstype (relatief)

$\begin{array}{lcc}\text { Variabele } & \text { Parameter } & \text { T-waarde } \\ \text { Constante } & -1,04 & -0,63 \\ \text { Schaal } & 0,68 & 4,31^{* *} \\ \text { Spreidingsindicator beroepen } & 0,01 & 0,24 \\ \text { Spreidingsindicator sectoren } & 0,03 & 0,72 \\ \text { Percentage vrouwen } & 0,01 & 1,05 \\ \text { Onderschattingscoëfficiënt } & 0,00 & 1,23 \\ \text { Conjunctuur } & 0,65 & 0,62\end{array}$

* significant bij betrouwbaarheid van $90 \%$

** significant bij betrouwbaarheid van 95\%

Naast de bovengenoemde verklaringen is er echter nog een additionele factor die de voorspelfouten heeft beinvloed. Een belangrijke factor is dat het CBS het aantal werkenden per opleidingstype, gebaseerd op de Enquête Beroepsbevolking (EBB), heeft aangepast nadat het ROA de gegevens van het aantal werkenden in het basisjaar (2000) heeft gebruikt voor het samenstellen van de prognoses in $2001 .^{3}$ Als gevolg hiervan zijn er grote verschillen zichtbaar tussen de aantallen werkenden in bepaalde opleidingstypen in 2000. Ter illustratie, toen het ROA de prognoses maakte, waren volgens de EBB ruim 580.000 mensen werkzaam met het opleidingtype Basisonderwijs (ongeschoolden dus). Na de aanpassing door het CBS (die dus plaatsvond nadat de prognoses waren opgesteld) is het antal werkenden met een opleiding Basisonderwijs in 2000 bijgesteld naar 470.000. Ofwel, het aantal werkenden is met $23 \%$ naar beneden bijgesteld. Dit kan een belangrijke

3. Bij de beroepsgroepen hebben dergelijke aanpassingen overigens nauwelijks plaatsgevonden. 
verklaring zijn voor de overschatting van de vervangingsvraag voor dit opleidingstype. Deze overschatting is dus niet het gevolg van de kwaliteit van het prognosemodel, maar komt tot stand door ex-post veranderingen in de data. Als Basisonderwijs niet wordt meegenomen in de berekening van het gemiddeld verlies, dan is het gemiddeld verlies aanzienlijk lager ( 0,0131 voor de absolute en 0,0037 voor de relatieve vervangingsvraag). Tevens, de score voor de absolute vervangingsvraag daalt dan tot 1,42 , terwijl die voor de relatieve vervangingsvraag afneemt tot 1,88. Hieruit blijkt dus duidelijk dat de ex-post anpassingen van het aantal werkenden in de EBB-gegevens grote gevolgen hebben voor de evaluatie.

Om het effect van de veranderingen in de data ook in kaart te brengen voor alle opleidingstypen, is een regressie geschat waarin de voorspelfouten in de vervangingsvraagprognoses per opleidingstype worden verklaard door de afwijking tussen de EBB-gegevens van het jaar 2000 die beschikbaar was ten tijde van het samenstellen van de prognoses in 2001 en de EBB-gegevens van het jaar 2000 die nu zijn gebruikt voor deze evaluatiestudie. De regressieresultaten zijn weergegeven in Tabel 3.8. De tabel laat zien dat de afwijking per opleidingstype tussen de EBB data die voor het basisjaar beschikbaar waren ten tijde van de prognose en na de bijstelling de voorspelfout significant beinvloedt. Een toename van de afwijking in de EBB-data met 1\% leidt tot een toename van de voorspelfout met $0,25 \%$.

\section{Tabel 3.8}

Afwijking EBB als verklaring van voorspelfouten in de vervangingsvraagprognoses per opleidingstype (relatief)

$\begin{array}{lcc}\text { Variabele } & \text { Parameter } & \text { T-waarde } \\ \text { Constante } & 5,14 & 8,42^{* *} \\ \text { Afwijking EBB data } & 0,25 & 3,25^{* *} \\ \text { * significant bij betrouwbaarheid van 90\% } & & \\ \text { ** significant bij betrouwbaarheid van 95\% } & & \end{array}$




\section{Kwalitatieve typeringen}

Evenals bij de vervangingsvraagprognose per beroepsgroep, is bij de vervangingsvraag per opleidingstype een kwalitatieve typering gemaakt. De indeling van de kwalitatieve typeringen is als volgt:

$\begin{array}{rlrl} & \mathrm{VVO} \leq 8 \% & \text { erg laag } \\ 8 \%<\mathrm{VVO} \leq 13 \% & \text { laag } \\ 13 \%<\mathrm{VVO} \leq 20 \% & \text { gemiddeld } \\ 20 \%<\mathrm{VVO} \leq 25 \% & \text { hoog } \\ 25 \%<\mathrm{VVO} & & \text { erg hoog }\end{array}$

waarbij VVO staat voor vervangingsvraag per opleidingstype.

Tabel 3.9 geeft een overzicht van de voorspelde kwalitatieve typeringen en de realisaties. De tabel laat zien dat in 33 van de 104 gevallen (32\%) de prognose een exact juiste typering heeft gekregen. Daarnaast wijkt bij 46 opleidingstypen (44\%) de voorspelde typering slechts één categorie af van de realisatie. Dit betekent dat voor $76 \%$ van het totaal aantal opleidingstypen sprake is geweest van een juiste of redelijk juiste typering. Dit is een lichte verslechtering ten opzichte van de prognose voor 2002, waarvan $36 \%$ van de typeringen exact goed en $84 \%$ bijna goed waren.

Het aantal opleidingstypen waarvoor een verkeerde richting werd gemeten is beperkt. In totaal wordt er voor 14 opleidingstypen die de volgens de prognose de typering 'laag' of 'erg laag' hadden een gerealiseerde vervangingsvraag 'hoog' of 'erg hoog' waargenomen. Dit komt overeen met $13 \%$ van het totaal. De grootste voorspelfouten zijn waarneembaar voor $M B O$ geld, bank en belastingen en $H B O$ secretariaat. Beide opleidingstypen hadden ook de grootste voorspelfout van de (absolute) vervangingsvraagprognose. Samenvattend blijkt dat ondanks dat de kwaliteit van de prognoses achteruit is gegaan, de typering alsnog vrij goed wordt voorspeld. 
Tabel 3.9

Typeringen van de vervangingsvraag per opleidingstype

$\begin{array}{lcccccc}\text { Prognose } & \text { erg laag } & \text { laag } & \text { gemiddeld } & \text { hoog } & \text { erg hoog } & \text { Totaal } \\ \text { Erg laag } & 7 & 12 & 7 & 4 & 4 & 34 \\ \text { Laag } & 10 & 17 & 16 & 2 & 1 & 46 \\ \text { Gemiddeld } & 2 & 5 & 7 & 3 & 0 & 17 \\ \text { Hoog } & 0 & 2 & 0 & 1 & 0 & 3 \\ \text { Erg hoog } & 1 & 0 & 2 & 0 & 1 & 4 \\ \text { Totaal } & 20 & 36 & 32 & 10 & 6 & 104\end{array}$

\section{Conclusies}

Uit de empirische evaluatie van de vervangingsvraagprognoses per opleidingstype kunnen de volgende conclusies getrokken worden. Evenals bij de prognoses per beroepsgroep is er sprake geweest van een zekere overschatting van de vervangingsvraag in de periode van 2001 tot 2006.

Het gemiddelde verlies is zowel toegenomen voor de absolute prognoses als voor voor de relatieve prognoses. Ook hier geldt dat vooral de verdeling over de verschillende opleidingstypen verslechterd is geworden. Omdat de score groter is dan 1 , is de referentieprognose nog steeds beter. De verslechtering van de prognoses zijn echter maar deels terug te brengen op het prognosemodel. Zoals is gebleken, worden de voorspelfouten ook veroorzaakt door ex-post aanpassingen van de EBB data. Desondanks, als wordt gekeken naar de typering van de vervangingsvraag per opleidingstype, dan blijkt dat de prognoses in de meeste gevallen nog steeds een juiste of bijna juiste typering gaf van de gerealiseerde vervangingsvraag.

\section{Vergelijking realisatie cohort-componenten- methode en paneldata}

Tot dusver is voor de vervangingsvraagprognoses altijd gebruik gemaakt van de cohort-componenten-methode. De vervangingsvraag is echter een afgeleide van de 
verschillende stromen op de arbeidsmarkt, waardoor voor het vaststellen van de vervangingsvraag het beste bruto stroomcijfers gehanteerd kunnen worden. De primaire reden voor de keuze om gebruik te maken van de cohort-componentenmethode is dat voorheen geen paneldata beschikbaar zijn waaruit deze stromen konden worden vastgesteld. Sinds kort zijn deze gegevens wel beschikbaar. Uit de Enquête Beroepsbevolking (EBB) kunnen panelgegevens over beroepenmobiliteit worden gebruikt. Dit stelt ons in staat om te analyseren in hoeverre de realisatie op basis van de cohort-componenten-methode, die is gebaseerd op crossectionele EBB-data, overeenkomt met de uitstroomcijfers op basis van de EBBpanelgegevens voor de periode tot 2006 .

Omdat op basis van de cohort-componenten-methode alleen nettostromen kunnen worden bepaald, wordt derhalve de realisatie vergeleken met de gerealiseerde netto uitstroomcijfers van het EBB-panel. Daarbij is het relevant om op te merken dat de uitstroomcijfers wel van elkaar afwijken aangezien de netto stromen op basis van het EBB-panel voor deze studie nog niet op cohortniveau zijn vastgesteld. Hierdoor zal het gemiddeld verlies wat hoger zijn. Naast deze vergelijking wordt de cohortcomponenten-methode ook afgezet tegen een referentierealisatie. De gemiddelde gerealiseerde vervangingsvraag als percentage van het aantal werkzame personen wordt gebruikt als een referentierealisatie voor de vervangingsvraag per beroep of opleiding.

Tabel 4.1 geeft het gemiddelde verlies weer van de vervangingsvraagprognose op basis van de cohort-componenten-methode (CCM) en de referentierealisatie. De tabel laat zien dat het gemiddelde verlies van de cohort-componenten-methode kleiner is dan van de referentierealisatie. De verliezen zijn wel hoger dan die van de eerder besproken vervangingsvraagprognoses. Dit kan echter verklaard worden door het feit dat hier de vervangingsvraag op verschillende manieren is berekend, terwijl eerder de prognose en de realisatie, die beide waren gebaseerd op de cohortcomponenten-methode, met elkaar werden vergeleken. De tabel laat verder zien dat de CCM-realisatie van de vervangingsvraag zowel absoluut als negatief een 
betere voorspeller is van de netto uitstroom op basis van het EBB-panel dan de referentierealisatie van de vervangingsvraag. Voor de absolute en relatieve score realisatie wordt een score gevonden van 0,91 respectievelijk 0,88 . Dit toont aan dat de uitkomsten van de cohort-componenten-methode dus sterker gecorreleerd zijn met de netto uitstroom op basis van de paneldata dan de referentierealisatie. De correlaties worden in de onderste rij van de tabel weergegeven. De correlatiecoefficient tussen de realisatie op basis van het EBB-panel en de cohort componenten methode is 0,502 . De correlatiecoefficient tussen de netto uitstroom op basis van het EBB-panel en de referentierealisatie is lager $(0,414)$.

\section{Tabel 4.1}

Totaaloverzicht voorspelkwaliteit realisatie netto-uitstroom cohortcomponentenmethode en panel data

\begin{tabular}{|c|c|c|c|}
\hline Methode & $\begin{array}{c}\text { Gem. verlies } \\
\text { CCM-realisatie }\end{array}$ & $\begin{array}{c}\text { Gem. verlies } \\
\text { referentierealisatie }\end{array}$ & Score \\
\hline \multicolumn{4}{|l|}{ Netto-uitstroom } \\
\hline Absoluut & 0,0890 & 0,0975 & 0,91 \\
\hline Relatief & 0,0794 & 0,0900 & 0,88 \\
\hline Correlatie met netto uitstroom in EBB-panel & $\begin{array}{r}\text { CCM-realisatie } \\
0,502\end{array}$ & $\begin{array}{c}\text { Referentierealisatie } \\
0,414\end{array}$ & \\
\hline
\end{tabular}

\section{Conclusies}

In dit rapport zijn de vervangingsvraagprognoses geëvalueerd die samengesteld zijn in 2001 en betrekking hadden op de verwachte vervangingsvraag naar opleiding en beroep voor de periode tot 2006. In dit slothoofdstuk wordt in het kort een overzicht gegeven van de belangrijkste bevindingen. De resultaten worden samengevat door deze te vergelijken met die van de kwaliteit van de voorgaande prognoses.

Tabel 5.1 laat het gemiddeld verlies voor de relatieve vervangingsvraag zien. Zoals in de voorafgaande evaluaties wordt het grootste gemiddelde verlies waargenomen voor de vervangingsvraagprognose per opleidingstype. Het gemiddeld verlies is echter in vergelijking met de eerdere prognoses relatief hoog. Het gemiddeld verlies per beroepsgroep is ten opzichte van de vorige prognose gestegen van 0,0024 naar 
0,0042. Het gemiddeld verlies per opleidingstype nam toe van 0,0032 naar 0,0056. Met andere woorden, de kwaliteit van de vervangingsvraagprognoses is achteruit gegaan. Daarbij dient echter te worden opgemerkt dat de verslechtering van de vervangingsvraagprognoses per opleidingstype maar deels terug te brengen is op het prognosemodel. Zoals is gebleken, worden de voorspelfouten ook grotendeels veroorzaakt door ex-post aanpassingen van de EBB-data die betrekking hebben op het aantal werkenden per opleidingstype in het basisjaar van de prognose. Vooral voor de evaluatie van de vervangingsvraagprognose voor Basisonderwijs blijkt dat de ex-post aanpassingen grote gevolgen kan hebben. Zonder de ex-post aanpassingen zou het gemiddeld verlies een stuk lager liggen en zouden de scores aanzienlijk beter zijn. Dit roept tevens de vraag op in welke mate een toename van de betrouwbaarheidsintervallen in de Enquête Beroepsbevolking (EBB) na de laatste evaluatiestudie voor de vervangingsvraag tot 2002 (samengesteld in 1997) verantwoordelijk kunnen zijn voor de slechtere resulaten.

\section{Tabel 5.1}

Het gemiddelde verlies voor de relatieve vervangingsvraag

\begin{tabular}{l|cccccc} 
Prognoses tot & 2006 & 2002 & 2000 & 1998 & 1994 & 1992 \\
Beroepsgroep & 0,0042 & 0,0024 & 0,0026 & 0,0019 & 0,0022 & 0,0180 \\
Opleidingstype & 0,0056 & 0,0032 & 0,0022 & 0,0021 & 0,0022 & 0,0039
\end{tabular}

Tabel 5.2 geeft een overzicht van de scores van de vervangingsvraag. De scores van de vervangingsvraagprognoses laten zien dat de referentieprognose zowel absoluut als relatief gezien een betere voorspeller is van de vervangingsvraag. Ten opzichte van de scores in voorafgaande evaluaties zijn de scores relatief hoog. Ook hier geldt dat de vervangingsvraagprognoses slechter zijn geworden. 
Tabel 5.2

De score voor de relatieve vervangingsvraag

$\begin{array}{lrrrrrr}\text { Prognoses tot } & 2006 & 2002 & 2000 & 1998 & 1994 & 1992 \\ \text { Beroepsgroep } & 1,33 & 1,10 & 1,23 & 1,08 & 1,39 & 1,00 \\ \text { Opleidingstype } & 2,34 & 0,91 & 1,37 & 2,03 & 2,26 & 0,96\end{array}$

Ondanks de verslechtering in de kwaliteit van de prognoses en de ex-post aanpassingen in de EBB-data blijkt echter ook dat de prognoses in de meeste gevallen nog steeds een juiste of bijna juiste typering gekregen hebben voor de verschillende opleidingstypen en beroepsgroepen. De voorspelkwaliteit van de typeringen per beroepsgroep is echter wel vrij laag in verhouding tot de voorgaande evaluaties. De voorspelkwaliteit van de typeringen per opleidingstype is relatief goed. ${ }^{4}$

Tabel 5.3

Voorspelkwaliteit typeringen voor de prognoses van de relatieve vervangingsvraag

$\begin{array}{lcccccc}\text { Prognoses tot } & 2006 & 2002 & 2000 & 1998 & 1994 & 1992 \\ & \% & \% & \% & \% & \% & \% \\ \text { Beroepsgroep } & 27 & 34 & 45 & 52 & 32 & 29 \\ \text { geheel juist } & 63 & 80 & 76 & 73 & 76 & 62 \\ \text { max. 1 categorie ernaast } & & & & & & \\ \begin{array}{l}\text { Opleidingstype } \\ \text { geheel juist }\end{array} & 32 & 36 & 25 & 34 & 32 & 26 \\ \text { max. 1 categorie ernaast } & 76 & 84 & 57 & 77 & 60 & 47\end{array}$

We kunnen concluderen dat de kwaliteit van de vervangingsvraagprognoses tot 2006 slechter is dan de prognoses bij de laatste evaluatie. Het gemiddeld verlies van alle prognose-onderdelen is omhoog gegaan ten opzichte van de eerdere prognoses. Voor de opleidingstypen kan dit slechts deels aan de kwaliteit van het prognosemodel worden toegeschreven. Dupuy (2005) was nog hoopvol ten aanzien van de introductie van het zogenaamde random coëfficiënten model in de prognoses tot 2002. Deze prognoses waren wat betreft de score van de vervangingsvraagprognose naar opleiding, de beste tot dan toe. De vervangingsvraagprognoses

4. Voor de prognoses tot 2000 (prognosejaar 1995) hebben overigens uitbreidingen van het aantal opleidingstypen en beroepsgroepen plaatsgevonden, zodat de verschillende indicatoren voor de kwaliteit van de prognoses niet helemaal vergelijkbaar zijn over de tijd. 
scoren deze keer echter ook voor de opleidingstypen weer minder goed in vergelijking met de referentieprognose.

Tot slot is het van belang op te merken dat de beoordeling van de kwaliteit prognoses ook afhangt van de wijze waarop geëvalueerd wordt en data die gebruikt worden bij de evaluatie. Zo is gebleken dat aanpassingen in de EBB achteraf (dus nadat de prognoses gemaakt zijn), van grote invloed kunnen zijn op de evaluatie.

Een toename van de afwijking in de EBB-data met 1\% leidt tot een toename van de voorspelfout met $0,25 \%$. Daarnaast is het opvallend dat de score van de vervangingsvraagprognoses beter scoren ten opzichte van de referentieprognose als er bij de evaluatie gebruik wordt gemaakt van de onlangs beschikbaar gekomen panelgegevens van de EBB. Voor de toekomst zal overigens geprobeerd worden om de gegevens uit het EBB-panel ook te gebruiken voor het samenstellen van de vervangingsvraag. Deze informatie kan in elk geval van dienst zijn om meer zicht te krijgen op de bruto en netto uitstroompatronen op de arbeidsmarkt en de vervangingsvraag per beroepsgroep en opleidingstype.

\section{Literatuur}

Borghans, L. (1993), Educational Choice and Labour Market Information, proefschrift, ROA, Universiteit Maastricht.

Borghans, L. , P. van Eijs, A. de Grip (1994), Evaluatie arbeidsmarktprognoses naar opleiding en beroep in 1992, ROA-R-1994/4, Maastricht.

Clements, M.P. (1995), Rationalty and the role of judgement in macroeconomic forecasting, Economic Journal, Vol. 105, pp. 410-420.

Cörvers, F., B.J. Diephuis, S. Dijksman, B. Golsteyn, M. Hensen, Ph. Marey (2002), Methodiek arbeidsmarktprognoses en -indicatoren 2001-2006, ROA-W-2002/4, Maastricht.Cörvers, F., Dupuy, A. (2005), An Evaluation of labour market forecasts by type of education and occupation for 2002, ROA-W-2005/1E, Maastricht.

Granger, C.W.J., P. Newbold (1986), Forecasting Economic Time Series, Orlando.

ROA (2001), De arbeidsmarkt naar opleiding en beroep tot 2006, ROA-R-2001/8, Maastricht. 
ROA (2007), De arbeidsmarkt naar opleiding en beroep tot 2012, ROA-R-2007/4, Maastricht.

Grip, A. de, J.A.M. Heijke en H. Berendsen (1991), Eerste evaluatie informatiesysteem onderwijsarbeidsmarkt, ROA-R-1991/1, Maastricht.

Smits, W., en B. Diephuis (2001), Evaluatie arbeidsmarktprognoses naar opleiding en beroep tot 1998, ROA-R-2001/2, Maastricht.

Theil, H. (1958). Economic Forecasts and Policy, Amsterdam.

Wieling, M., L. Borghans (1995), Discrepancies between Demand and Supply and Adjustment Processes on the Labour Market, ROA-RM-1995/4E, Maastricht.

Willems, E.J.T.A., A. de Grip (1993), Forecasting Replacement Demand by Occupation and Education, International Journal of Forecasting, vol. 9, pp. 173-185.

Willems, E. (1996), Manpower Forecasting and Modelling Replacement Demand: an Overview, ROA-W-1996/4E, Maastricht. 